Estudios Constitucionales, Año 16, No 1, 2018 pp. 281-326

ISSN 07180195

Centro de Estudios Constitucionales de Chile Universidad de Talca

"Admisión y expulsión de extranjeros en el derecho argentino"

Fernando Arlettaz

\title{
ADMISIÓN Y EXPULSIÓN DE EXTRANJEROS EN EL DERECHO ARGENTINO
}

\author{
ADMisSiON AND EXPULSION OF ALIENS IN ARGENTINIAN LAW*
}

\author{
FERnANDO ARLETTAZ ${ }^{* *}$ \\ Consejo Nacional de Investigaciones Científicas y Técnicas \\ Universidad de Buenos Aires \\ fernandoarlettaz@conicet.gov.ar
}

RESUMEN: La Constitución argentina, aunque proyectó una politica migratoria generosa, dio a la autoridad estatal competencia para regular el ingreso y la salida de extranjeros. La legislación y la jurisprudencia aplicaron las cláusulas constitucionales respectivas de manera variable, según las circunstancias políticas de cada época. Tales cláusulas deben ser hoy leidas de conformidad con el derecho internacional de los derechos humanos.

PALABRAS CLAVE: admisión de extranjeros, expulsión de extranjeros, derecho constitucional argentino, derechos humanos.

ABSTRACT: The Argentinian Constitution, although it established a generous immigration policy, recognised the State authority to regulate the entry and exit of aliens. The respective constitutional clauses have been applied through legislation and jurisprudence in a changing way, according to the political circumstances of the time. Such clauses must now be interpreted in accordance with the international law of human rights.

KEYWORDS: admission of aliens, expulsion of aliens, Argentinian constitutional law, human rights.

\section{INTRODUCCIÓN}

La historia argentina es en buena medida la historia de sus inmigrantes. De los extranjeros que llegaron de los lugares más recónditos y se incorporaron a un proyecto nacional en ciernes. No es necesario insistir demasiado sobre este hecho.

\footnotetext{
* Artículo recibido el 3 de febrero de 2017 y aprobado el 18 de abril de 2018.

** Doctor en Sociología Jurídica e Instituciones Políticas. Sus campos de trabajo son el derecho público y la filosofía/sociología jurídicas. Sus investigaciones abordan las migraciones y el estatuto de los extranjeros, la libertad de conciencia y la laicidad del Estado y los derechos de las minorías, entre otros temas.
} 
Según el censo nacional de 2010, aproximadamente el 4,5\% de los habitantes del país había nacido en el extranjero. Aunque esta cifra está por supuesto muy lejos de las de otras épocas (el país llegó a tener un tercio de su población nacida en el extranjero), ella se traduce en el no poco significativo dato de un millón ochocientas mil personas que viven en el país pero han nacido fuera de él ${ }^{1}$.

Los constituyentes de 1853 vieron en la inmigración uno de los elementos clave en la construcción del Estado y el desarrollo económico del territorio. Y adoptaron en consecuencia una política de puertas abiertas. Sin embargo, ni la Constitución de 1853 ni ninguna de sus reformas posteriores equipararon totalmente a los extranjeros con los nacionales argentinos, ni establecieron un derecho ilimitado a ingresar y permanecer en el territorio. Aunque muy generosa con la inmigración, la Constitución no significó una renuncia a la potestad soberana del Estado, reconocida inequívocamente por el derecho internacional, de establecer las condiciones de entrada y permanencia de los extranjeros en su territorio y de regular sus derechos de la manera que estimara más conveniente.

A partir de entonces, una compleja sucesión de leyes y decretos especificó el proyecto constitucional. Algunas normas, como la Ley Avellaneda que posibilitó la entrada de grandes grupos inmigrantes, fueron decididamente protectoras de la inmigración. Otras, como la Ley de Residencia o la Ley Videla, asumieron en cambio que la inmigración era una problemática de orden público y seguridad nacional, y se centraron en medidas restrictivas.

El objetivo de este artículo es estudiar los principios generales relativos a la admisión y la expulsión de extranjeros en el derecho argentino. No se pretende abordar toda la temática de la regulación del estatuto de extranjería. Así, la fundamental cuestión de los derechos de los extranjeros que se encuentran en el territorio (de modo regular o irregular) en materia laboral, educativa o sanitaria no es aquí tratada. Lo que nos interesa es la regulación de las condiciones de entrada y salida del territorio, es decir, la cuestión de quién tiene derecho a entrar y quedarse en el país.

1 Instituto Nacional de Estadística y Censos (2010). La consideración del lugar de nacimiento a los efectos que aquí nos interesan sirve por supuesto sólo como una aproximación general. Es posible que haya personas nacidas en el extranjero que no sean de nacionalidad extranjera (porque son hijos de argentinos que han optado por la nacionalidad de sus padres o porque son personas que originalmente tenían una nacionalidad extranjera pero han adquirido nacionalidad argentina por naturalización, por ejemplo). El supuesto inverso (personas nacidas en el país pero de nacionalidad extranjera) es muchísimo más excepcional, teniendo en cuenta las contadísimas excepciones posibles a la adquisición de la nacionalidad argentina por ius soli. 
La pregunta que guía el trabajo es la pregunta relativa a la interpretación de los principios generales de la Constitución y del derecho internacional por el legislador y la jurisprudencia. En este sentido, la hipótesis que se plantea es que esa interpretación ha variado a lo largo del tiempo en función de los proyectos políticos imperantes. Así, durante el siglo XIX prevaleció una perspectiva liberal congruente con la idea de atraer inmigrantes al país, pero a comienzos del siglo XX esa perspectiva se vio matizada (sin desaparecer totalmente) por la percepción de que era necesario controlar de alguna manera a los inmigrantes peligrosos que supusieran un riesgo para la estructura social. Más tarde, la doctrina de la seguridad nacional impregnó la interpretación dominante durante la segunda mitad del siglo $\mathrm{XX}$, en el contexto de reiterados golpes militares que rompieron la continuidad institucional. Finalmente, la restauración democrática llevó, lentamente, al establecimiento de un sistema más garantista.

Los dos eventos más importantes en relación con nuestro tema en las últimas décadas han sido la incorporación al texto constitucional de ciertos instrumentos internacionales en materia de derechos humanos ${ }^{2}$ y la aprobación de la vigente Ley de Migraciones. Como veremos, ambos hechos han supuesto una creciente humanización del tratamiento jurídico del fenómeno migratorio, en la medida en que han reforzado las garantías ofrecidas a quien pretende entrar o permanecer en el territorio argentino. En la dinámica derechos humanos / soberanía estatal, el primer elemento ha salido reforzado y el segundo ha perdido intensidad.

Sin embargo, esto no ha significado de modo alguno la evaporación de la soberanía estatal en lo que respecta a la admisión y expulsión de extranjeros. $\mathrm{Ni}$

2 La reforma constitucional de 1994 otorgó jerarquía constitucional a los siguientes instrumentos internacionales: Declaración Americana de los Derechos y Deberes del Hombre; Declaración Universal de Derechos Humanos; Convención Americana sobre Derechos Humanos; Pacto Internacional de Derechos Económicos, Sociales y Culturales; Pacto Internacional de Derechos Civiles y Políticos y su Protocolo Facultativo; Convención sobre la Prevención y la Sanción del Delito de Genocidio; Convención Internacional sobre la Eliminación de todas las Formas de Discriminación Racial; Convención sobre la Eliminación de todas las Formas de Discriminación contra la Mujer; Convención contra la Tortura y otros Tratos o Penas Crueles, Inhumanos o Degradantes; Convención sobre los Derechos del Niño. Con posterioridad, el legislador otorgó jerarquía constitucional a la Convención Interamericana sobre Desaparición Forzada de Personas, a la Convención sobre Imprescriptibilidad de los Crímenes de Guerra y de los Crímenes de Lesa Humanidad y a la Convención sobre los Derechos de las Personas con Discapacidad. A lo largo del trabajo nos ocuparemos de los instrumentos con jerarquía constitucional que resulten pertinentes, así como de otros dos tratados específicos pero sin jerarquía constitucional (la Convención sobre el Estatuto de los Refugiados y la Convención Internacional sobre la Protección de los Derechos de Todos los Trabajadores Migratorios y sus Familiares (a partir de ahora, Convención sobre Trabajadores Migratorios). Para algunas clarificaciones conceptuales sobre el régimen de las migraciones en el contexto interamericano, ver ARLETTAZ (2014). 
los tratados internacionales ni la actual Ley de Migraciones han reconocido un derecho irrestricto de los extranjeros a entrar o permanecer en el territorio argentino. Ni siquiera el general reconocimiento del derecho a la migración con carácter de "esencial e inalienable" y la obligación estatal de garantizarlo "sobre la base de los principios de igualdad y universalidad" establecido en la Ley de Migraciones ${ }^{3}$ alcanzan para borrar totalmente la soberana potestad estatal de admitir y expulsar extranjeros. Esto es así porque tal derecho a migrar está reconocido sólo sobre base legal (ni la Constitución ni los instrumentos internacionales autorizan una lectura tan amplia de la libertad de circulación); y porque la cláusula legal que consagra el derecho a migrar debe leerse en sintonía con las demás cláusulas de la misma ley que establecen quiénes y bajo qué condiciones tienen ese derecho a migrar (es decir, quiénes y bajo qué condiciones tienen derecho a entrar y permanecer en el territorio).

\section{EVOLUCIÓN HISTÓRICA}

\section{Proyecto constitucional}

El texto constitucional aprobado en 1853 y que está todavía en vigor, con las reformas que se sucedieron desde entonces, estaba particularmente interesado en la promoción de la inmigración. El texto de 1853 se inspiró en la máxima alberdiana gobernar es poblar, y trazó un proyecto de población del extenso territorio argentino a través de la inmigración europea. El preámbulo abrió las puertas del país a todos aquellos que quisieran venir a poblarlo: los objetivos en él enunciados lo son "para nosotros, para nuestra posteridad, y para todos los hombres del mundo que quieran habitar en el suelo argentino". Ya desde el inicio los constituyentes argentinos se apartaron del modelo norteamericano que limitaba el beneficio de los objetivos constitucionales "to ourselves and our posterity" (lo que no impidió por supuesto la llegada masiva de inmigrantes también al país del norte).

La promoción de la inmigración fue establecida como una competencia compartida entre la Nación y las provincias ${ }^{4}$. En lo que se refiere al gobierno federal, sus obligaciones en esta materia están establecidas, desde 1853, en el art.

${ }^{3}$ Ley No 25.871 (2004), art. 4º.

${ }^{4}$ Constitución de la Nación Argentina (1853), arts. 64.16 y 104; Constitución de la Nación Argentina (1860), arts. 67.16 y 107; Constitución de la Nación Argentina (1994), arts. 75.18 y 125. 
25, vigente sin cambios desde entonces: "El Gobierno federal fomentará la inmigración europea; y no podrá restringir, limitar ni gravar con impuesto alguno la entrada en el territorio argentino de los extranjeros que traigan por objeto labrar la tierra, mejorar las industrias, e introducir y enseñar las ciencias y las artes"5.

Este artículo se inspira en el artículo 33 del proyecto constitucional de Juan Bautista Alberdi, aunque es un poco más restrictivo en su letra. El proyecto de Alberdi establecía, en efecto, que "la inmigración no podrá ser restringida, ni limitada de ningún modo en ninguna circunstancia, ni por pretexto alguno". Alberdi creía que la inmigración no debía ser limitada de manera alguna; la Constitución de 1853, en cambio, sólo prohíbe limitar la inmigración útil (es decir, aquella que puede aportar algo en términos de desarrollo del país).

Esta circunstancia torna evidente que la política migratoria de la Constitución de 1853 no estaba basada en una (entonces inexistente) concepción de un derecho humano a migrar como parte del desarrollo de un plan personal de vida, sino en un proyecto de desarrollo económico y social de carácter colectivo. La migración promovida por la Constitución se subordina a ese objetivo, y por eso la Constitución hace una distinción entre extranjeros bienvenidos y extranjeros no bienvenidos. Como dirá años más tarde una Cámara Federal, los extranjeros que no son bienvenidos "no pueden aducir un derecho individual más poderoso que el de la soberanía del Estado en que se funda el derecho de impedirles su entrada al país o el de expulsarlos de su seno, si ya hubieran entrado"6.

Los instrumentos internacionales constitucionalizados en 1994 tienen una incidencia importante en las políticas de admisión y expulsión de extranjeros. La interpretación del texto constitucional de 1853 a la luz de los principios contenidos en esos textos impone hoy soluciones diferentes a las aceptadas en otras épocas. A lo largo de este trabajo mencionaremos los aspectos más significativos de esta cuestión. Sin embargo, esto no desvirtúa el hecho esencial de que el Estado sigue manteniendo la potestad de definir su política migratoria y, en consecuencia, establecer criterios de admisión y expulsión de extranjeros.

La Constitución de 1853, además de la prohibición de limitar la inmigración, impone al gobierno federal el deber de promoverla. Esta promoción se refiere, en el texto expreso de la Constitución, sólo a la inmigración europea. Es muy posible

5 Constitución de la Nación Argentina, art. 25 (idéntico y con la misma numeración en las versiones de 1853,1860 y 1994).

6 Transporte Chaco, Cámara Federal de Apelaciones de la Capital, 1932. 
que una interpretación literal de esta disposición resulte hoy incompatible con el texto de los instrumentos internacionales en materia de derechos humanos. Si alguna operatividad se le adjudica todavía hoy a la función promotora de la inmigración que ha de asumir el Estado, ella debería hacerse sin distinción alguna sobre las bases de discriminación prohibidas por tales instrumentos (entre otras, la raza y el origen nacional).

\section{Habitantes y no habitantes}

El programa inmigratorio de la Constitución de 1853 se completaba con la igualdad civil entre nacionales y extranjeros consagrada en el art. 20, todavía vigente: "Los extranjeros gozan en el territorio de la Nación de todos los derechos civiles del ciudadano; pueden ejercer su industria, comercio y profesión; poseer bienes raíces, comprarlos y enajenarlos; navegar los ríos y costas; ejercer libremente su culto; testar y casarse conforme a las leyes [...]"7. Los extranjeros tienen pues los mismos derechos civiles que los ciudadanos. En el lenguaje constitucional del art. 20, el concepto de ciudadano se identifica con el de nacional.

Sin embargo, cuando la Constitución enuncia esos derechos civiles en el art. 14 no se refiere a los nacionales, sino a los habitantes. Para gozar de los derechos civiles reconocidos en la Constitución es necesario ser habitante del territorio. La distinción fundamental respecto de los extranjeros es, entonces, entre aquellos que pueden ser considerados habitantes y aquellos que no pertenecen a esta categoría. Los extranjeros habitantes gozan de todos los derechos civiles constitucionalmente reconocidos (entre ellos, el derecho de entrar, el de permanecer y el de salir del territorio argentino, que nos interesan en este trabajo). Estos derechos se tienen, claro está, "conforme a las leyes que reglamenten su ejercicio"8, es decir, a reserva de una reglamentación legal razonable.

Según una tradicional jurisprudencia de la Corte Suprema, para ser considerado habitante es necesario haber entrado y permanecido legalmente en el territorio y haber instalado allí la residencia o, al menos, tener intención de instalarla allî .

7 Constitución de la Nación Argentina, art. 20 (idéntico y con la misma numeración en las versiones de 1853,1860 y 1994, salvo una ligera variante formal).

8 Constitución de la Nación Argentina, art. 14 (idéntico y con la misma numeración en las versiones de 1853,1860 y 1994 , salvo una ligera variante formal).

9 Entre otros: Transporte Chaco, Corte Suprema de Justicia de la Nación (CSJN), Fallos, 164:344, 1932. Bertone, CSJN, Fallos 164:290, 1932. Psaradelis, CSJN, Fallos 171:310, 1934. Argüello Argüello, CSJN, Fallos 
Este criterio está bien asentado en la jurisprudencia del máximo tribunal, que sólo se ha apartado de él en algunos casos concretos ${ }^{10}$. Los extranjeros que no son habitantes no gozan de la igualdad de derechos civiles con los nacionales, aunque esto no quiere decir que carezcan de cualquier derecho constitucionalmente protegido. Así, por ejemplo, a los extranjeros que se encuentran fuera del país la Corte Suprema les ha reconocido el derecho de propiedad y el derecho de acceso a la jurisdicción argentina en relación con actos y derechos localizados en el país ${ }^{11}$. Y a los extranjeros que se encuentran dentro del país, pero de modo irregular, la Corte Suprema no les ha negado por este solo hecho el acceso a la jurisdicción, más allá de cuál fuera el resultado de sus reclamaciones en relación con la existencia o no de un derecho de entrar o permanecer en el país ${ }^{12}$.

Se debe tener en cuenta además que todos los extranjeros sujetos a la potestad del Estado argentino (estén dentro o fuera del territorio) pueden reivindicar los derechos que el estándar mínimo internacional reconoce respecto del trato a extranjeros. También pueden ampararse en los derechos reconocidos por los instrumentos internacionales de derechos humanos. Este último aspecto es de particular importancia, ya que en la medida en que las disposiciones de estos instrumentos consagren derechos de toda persona no será posible calificar su titularidad para restringirla a los habitantes. Así, por ejemplo, aunque las garantías judiciales del art. 18 de la Constitución tengan por titular a quien sea habitante de la Nación, ellas deben extenderse a cualquier individuo porque el art. $8^{\circ}$ de la Convención Americana reconoce las garantías judiciales a toda persona. Ahora bien: esto no ocurre con todos los derechos. Y ciertamente no ocurre con los derechos que aquí nos interesan. El derecho de entrar y el de permanecer en el territorio de un Estado no son reconocidos a toda persona por el derecho internacional de

268:393, 1967. Carrizo Coito, CSJN, Fallos, 302:604, 1980. La condición de la entrada legal fue explicitada por la Constitución de 1949 que estableció que los derechos civiles de los nacionales correspondían también a "los extranjeros que entren en el país sin violar las leyes" (art. 31).

10 En Maciá y Gassol la Corte consideró habitantes a dos personas que habían ingresado irregularmente al país. Sin embargo, como explicamos más abajo, había circunstancias muy particulares en torno de este caso. Maciá y Gassol, CSJN, Fallos 151:211, 1928.

11 Bunge, CSJN, Fallos 186:421, 1940. La Corte declaró inconstitucional, por violar el art. 17 relativo a la protección de la propiedad, la diferencia en el gravamen aplicado a las sucesiones según que el causante y el heredero fueran o no habitantes.

12 Ver la jurisprudencia de la CSJN citada a lo largo de este trabajo. Ver también la jurisprudencia de la Corte Interamericana de Derechos Humanos (Corte IDH) y de la Comisión Interamericana de Derechos Humanos (Comisión IDH) que se cita. 
los derechos humanos (aunque sí lo sea el de salir del territorio de un Estado). Volveremos sobre este punto más abajo.

Volviendo al concepto clásico de habitante, un último aspecto debe ser mencionado. En principio, para ser considerado habitante es necesario haber ingresado regularmente al país y haber permanecido en él de modo regular. Sin embargo, la jurisprudencia de la Corte Suprema ha admitido que el arraigo en el territorio puede purgar la irregularidad del ingreso o la irregularidad sobrevenida. Así, si después de haber entrado o permanecido irregularmente en el país el extranjero se estableció y arraigó en el territorio (en razón de su trabajo, del establecimiento de su familia, etc.) y no tiene antecedentes penales o policiales, el extranjero pasará a integrar la categoría de los habitantes del país. Esto significa que tendrá todos los derechos civiles reconocidos a los habitantes, entre ellos el derecho a permanecer de modo regular en el territorio (y, en consecuencia, a obtener la documentación que pruebe la regularidad de esa permanencia). Como dijo la Corte en el caso Cuesta Urrutia, "la rectitud del comportamiento en el país, unida a un transcurso de tiempo capaz de ponerlo a prueba y demostrar que responde a una leal voluntad de honrado arraigo" puede suplir el incumplimiento de las reglas sobre ingreso o permanencia regular en el territorio ${ }^{13}$.

El mismo criterio fue desarrollado con mayor detalle en la sentencia Lino Sosa. La Corte Suprema declaró que incluso quienes han ingresado irregularmente al país pueden ser considerados habitantes y, en consecuencia, obtener un derecho a permanecer en él si: 1) la entrada irregular no tuvo por finalidad ocultar antecedentes que habrían sido causa de un rechazo en la frontera; 2) durante ciertos años (la Corte no da un criterio general, pero en el caso eran cuatro), el extranjero se ha integrado a la vida nacional a través de su trabajo, del establecimiento de su domicilio en el país, etc.; 3) durante este tiempo, la autoridad migratoria no puso en marcha ningún procedimiento tendiente a su expulsión del país ${ }^{14}$.

13 Cuesta Urrutia, CSJN, Fallos 200:99, 1944. Caso relativo a un habeas corpus en beneficio de una persona detenida sobre la que pesaba una orden de expulsión en razón de su ingreso irregular al país. La sentencia de la Corte protege al extranjero frente a la expulsión.

14 Lino Sosa, CSJN, Fallos 234:203, 1956. La Corte Suprema consideró la situación de un marino que se había evadido de su barco y que había permanecido irregularmente en Argentina. Después de algunos años, el extranjero solicitó un permiso de residencia. Su solicitud fue rechazada y una orden de abandonar el país fue dictada. La Corte hizo lugar al habeas corpus en favor del antiguo marinero evadido. 


\section{Evolución legislativa}

La primera ley en materia de migraciones fue la Ley de Inmigración y Colonización de 1876, conocida bajo el nombre de Ley Avellaneda ${ }^{15}$. La ley tenía por finalidad la promoción de la inmigración. Ella no establecía un régimen general sobre el estatuto de los extranjeros, sino sólo reglas específicas sobre la colonización del territorio a partir de la entrada de extranjeros (aunque diversos decretos posteriores, dictados al amparo de esta u otras leyes, fueron regulando la situación de los extranjeros no comprendidos en esa ley). La ley definía al inmigrante como "todo extranjero jornalero, artesano, industrial, agricultor o profesor, que siendo menor de sesenta años, y acreditando su moralidad y sus aptitudes, llegase a la República para establecerse en ella, en buques a vapor o a vela, pagando pasaje de segunda o tercera clase, o teniendo el viaje pagado por cuenta de la Nación, de las provincias, o de las empresas particulares protectoras de la inmigración y la colonización"16. Para los inmigrantes así definidos, se preveían ciertas ventajas en materia de alojamiento, trabajo, etc.

La inmigración favorecida por la Ley de Inmigración y Colonización permitió la llegada masiva de extranjeros originarios de Europa. Entre ellos había militantes anarquistas, socialistas y sindicalistas. Como reacción a los movimientos sociales promovidos por estos militantes, la Ley de Residencia de 1902, conocida también como Ley Cané en razón de su autor ${ }^{17}$, autorizó al Poder Ejecutivo a ordenar la expulsión de todo extranjero perseguido por tribunales extranjeros por delitos comunes y de todo extranjero peligroso para la seguridad o el orden públicos ${ }^{18}$. Estos mismos extranjeros podían ser objeto de una denegación de entrada al momento de intentar ingresar al país ${ }^{19}$. Una vez que la expulsión era ordenada, el extranjero tenía tres días para salir del país y podía ser detenido hasta el momento del embarque ${ }^{20}$.

La ley tenía la clara finalidad de reprimir los movimientos sociales mencionados. En palabras de un observador de la época, el objetivo de la ley era "protejer

15 Ley No 817 (1876). Sobre la historia y el contexto legislativo, ver Novick (2008).

16 Ley No 817 (1876), art. 12.

17 Ley No 4.144 (1902).

18 Ley No 4.144 (1902), arts. $1^{\circ}$ y $2^{\circ}$.

19 Ley No 4.144 (1902), art. $3^{\circ}$.

20 Ley No 4.144 (1902), art. $4^{\circ}$. 
[sic] los intereses bien entendidos de la clase trabajadora, evitando que sus movimientos reivindicatorios de mejoras se viesen [...] exaltados y arrastrados por la prédica subversiva del orden jurídico y social establecido, de ciertos agitadores conocidos, perfectamente filiados, profesionales de este oficio, que viven de éste y que son la única causa de las perturbaciones actuales y que ponen en tanto peligro la libre circulación del comercio interno y externo de la República”. La inspiración biologicista de la ley tampoco era un secreto. El mismo observador continuaba diciendo que "en todos los pueblos civilizados se ha reconocido como un derecho inherente a la soberanía la [sic] de organizarse con exclusión de todos los elementos malsanos que puedan ser gérmenes de perturbación que no armonicen con la estructura constitucional a que la sociedad organizada obedece" (la cursiva es nuestra) ${ }^{21}$.

En 1910 fue dictada la Ley de Defensa Social ${ }^{22}$. Esta ley permitía la denegación de entrada a los condenados por ciertos delitos, a todos aquellos que atacaban el gobierno y las instituciones sociales y a aquéllos que habían sido previamente expulsados del territorio ${ }^{23}$. Estos mismos extranjeros, si conseguían entrar, podían ser expulsados ${ }^{24}$. Si los extranjeros expulsados en virtud de la Ley de Defensa Social o en virtud de la Ley de Residencia volvían a entrar en el territorio, estaban sujetos a una pena de entre tres y seis años de confinamiento, y una nueva expulsión luego de haber cumplido esta pena ${ }^{25}$.

Las relaciones entre ambas leyes no eran claras ${ }^{26}$. El Código Penal de 1921 abrogó la Ley de Defensa Social. La Corte Suprema interpretó, sin embargo, que esta abrogación no implicaba la abrogación de la Ley de Residencia, en lo que

21 Dictamen del Procurador Fiscal en Transporte Chaco, Juzgado de Primera Instancia (no se indica cuál), 1932.

22 Ley No 7.029 (1910).

23 Ley No 7.029 (1910), art. $1^{\circ}$.

24 Ley No 7.029 (1910), art. $4^{\text {o }}$.

25 Ley No 7.029 (1910), art. 5.

26 La Corte Suprema interpretó que la Ley de Defensa Social había derogado el art. $3^{\circ}$ de la Ley de Residencia, ya que para que la denegación de entrada fuera posible era necesaria una condena (y no la simple persecución por la justicia) y que se tratara de delitos específicos (la Ley de Residencia se refería a delitos de derecho común, mientras que la de Defensa Social exigía que fueran delitos que merecieran pena corporal según el Código Penal argentino). El resto de la Ley de Residencia, en particular en cuanto a la expulsión de extranjeros, continuaba en vigor, ya que la propia Ley de Defensa Social remitía a ella. Maciá y Gassol, CSJN, Fallos 151:211, 1928. 
no había sido afectada por la ley de Defensa Social27. La Ley de Residencia fue derogada en 1958, restablecida en 1969 y definitivamente derogada en 1973.

La conformidad de la Ley de Residencia con la Constitución fue declarada por la Corte Suprema en la sentencia Transporte Chaco. Desde un punto de vista sustantivo, la Corte consideró que la promoción de la inmigración predicada por la Constitución estaba limitada a la inmigración útil y que el Estado tenía en consecuencia el derecho de denegar la entrada o de expulsar a todos los extranjeros peligrosos o indeseables, que ponían en peligro la seguridad del Estado o la paz social. Desde un punto de vista procedimental, la Corte declaró que la expulsión no era una pena y que por ello las garantías constitucionales del proceso penal no eran aplicables. Sin embargo, ciertas garantías mínimas debían ser respetadas (ver más abajo) ${ }^{28}$.

Desde un punto de vista contemporáneo es posible decir que el control de constitucionalidad realizado por la Corte fue muy débil. La sola definición de un extranjero como peligroso es claramente insuficiente como caracterización de la situación que autoriza la expulsión. Además, las garantías procesales reconocidas por la ley (y avaladas por la Corte) eran muy reducidas. Sin embargo, tres puntos fundamentales deben ser resaltados en la sentencia Transporte Chaco: 1) las reglas sobre expulsión de extranjeros están sometidas al control de conformidad a la Constitución ejercitado por los jueces; 2) los jueces pueden controlar los motivos sustantivos de la expulsión establecidos en la ley y su aplicación concreta por parte de la Administración; 3) las expulsiones deben respetar ciertas garantías mínimas de procedimiento.

La Ley de Inmigración y Colonización fue reemplazada en 1981 por la Ley General de Migraciones y de Fomento de la Inmigración, conocida como Ley

27 Maciá y Gassol, CSJN, Fallos 151:211, 1928. CSJN, Transporte Chaco, Fallos 164:344, 1932.

28 Transporte Chaco, CSJN, Fallos 164:344, 1932. El caso era relativo a la expulsión de un amplio grupo de extranjeros que fueron llevados a sus países de origen (o a otros puertos extranjeros) a bordo del buque Chaco de la Armada. La mayoría de la Corte rechazó el habeas corpus interpuesto en su favor. Las valiosas disidencias de los ministros G. Lavalle y A. Sagarna sostuvieron la inconstitucionalidad de la Ley de Residencia con fundamento, entre otras cosas, en que la expulsión era una verdadera pena de destierro, que estaría siendo aplicada sin el juicio previo por los jueces naturales mencionado en el art. 18 de la Constitución y ejerciendo el Poder Ejecutivo funciones judiciales prohibidas en el entonces art. 95 de la Constitución. La validez de la Ley de Residencia fue reafirmada en sentencias posteriores (ver por ejemplo, Ordinanz, CSJN, Fallos 215:161, 1949, fallada bajo la vigencia de la Constitución de 1949 cuyo art. 31 preveía que la ley debía establecer "las causas, formalidades y condiciones" para "expulsar del país a los extranjeros" y en la que la Corte rechaza la acción a favor del extranjero). 
$V_{i d e l a}{ }^{29}$. Esta ley, dictada bajo la inspiración de la doctrina de la seguridad nacional, estaba fuertemente impregnada de una concepción de las migraciones como problemática de orden público. A diferencia de la Ley de Inmigración y Colonización, la Ley General de Migraciones y de Fomento de la Inmigración sí contenía un régimen general sobre el estatuto de los extranjeros. La ley fue reglamentada sucesivamente por dos decretos ${ }^{30}$. Es un hecho generalmente aceptado que el régimen de la Ley Videla favoreció el desarrollo de una lógica burocrática excesiva y de prácticas administrativas arbitrarias en la gestión estatal de las migraciones $^{31}$. Hace algo más de una década, la Ley General de Migraciones y de Fomento de la Inmigración fue sucedida por la Ley de Migraciones ${ }^{32}$, reglamentada unos años después ${ }^{33}$ y actualmente en vigor. Como veremos, la nueva ley, a pesar de su técnica legislativa francamente mejorable 34 , tiene un espíritu garantista mucho más acorde con los principios constitucionales y del derecho internacional de los derechos humanos. En el año 2017 se introdujeron en la ley cambios importantes que, sin alterar su sustancia, buscaron establecer un control más fuerte sobre algunos grupos de inmigrantes ${ }^{35}$.

\section{ENTRADA DE EXTRANJEROS}

\section{Principios constitucionales}

La Constitución de 1853 estableció el derecho de todos los habitantes de la Nación a entrar en el territorio argentino ${ }^{36}$. La lectura de este texto lleva sin embargo a una paradoja: para poder tener el derecho a entrar en el territorio es necesario ser habitante, es decir, estar ya dentro del territorio. Así, el derecho a entrar se vería reducido a un derecho a volver a entrar para aquellos que han

\footnotetext{
29 Ley No 22.439 (1981). Sobre la historia y el contexto legislativo, ver Novick (2008).

30 Decretos $\mathrm{No}^{\circ}$ s. 1434 (1987) y 1023 (1994).

31 Rodríguez Miglio y Toledo (2009).

32 Ley No 25.871 (2004). Sobre esta ley en general, ver Hines (2010), Novick (2008), Novick (2004) y Chausovsky (2004).

33 Decreto 616 (2010).

34 Gordillo (2004).

35 Sobre esta reforma ver GUASTI (2017).

36 Constitución de la Nación Argentina, art. 14 (idéntico y con la misma numeración en las versiones de 1853, 1860 y 1994, salvo una ligera variante formal).
} 
nacido en el territorio y han salido de él, y para aquellos que han nacido fuera del territorio, han sido admitidos en él y luego han salido.

Desde esta perspectiva, los extranjeros que no son habitantes no pueden reclamar un derecho constitucionalmente protegido a entrar por primera vez en el territorio. Los extranjeros tendrán o no derecho a entrar en el territorio de acuerdo con lo que la ley establezca. Una larga línea jurisprudencial de la Corte Suprema reconoce en efecto la potestad del Estado de impedir la entrada de extranjeros o de someterla a las formalidades y condiciones que estime convenientes ${ }^{37}$.

Este criterio de la Corte no parece haber sido afectado, en lo sustancial, por la inclusión constitucional de los instrumentos internacionales de derechos humanos, ya que ninguno de ellos reconoce un derecho a ingresar a un país que no sea el propio. Las normas americanas son muy claras. La Convención Americana reconoce el derecho a ingresar al Estado del que se es nacionaß ${ }^{8}$. La Declaración Americana reconoce el derecho a fijar la residencia en el Estado de la propia nacionalidad $^{39}$, con lo cual implícitamente admite un derecho de ingreso sólo para los nacionales.

Las normas del sistema universal son un poco más ambiguas. El Pacto Internacional de Derechos Civiles y Políticos dispone que nadie puede ser arbitrariamente privado del derecho a entrar en su propio pais ${ }^{40}$. La expresión su propio pais puede ser interpretada de modo más amplio que la expresión país de su nacionalidad y, en consecuencia, es posible que algunas personas puedan invocar un derecho a ingresar a un Estado que no es el de su nacionalidad. Sin embargo, el Comité de Derechos Humanos ha declarado que sólo en casos muy puntuales en los que exista una fuerte vinculación con el territorio podría una persona invocar un derecho a entrar en un país cuya nacionalidad no posee; y que por ello, dado que no existe un derecho protegido por el Pacto a ingresar a un país que no es el propio, tal entrada depende de una autorización de parte del Estado ${ }^{41}$. La Decla-

37 Magaz de González, CSJN, Fallos 148:410, 1926. Transporte Chaco, CSJN, Fallos 164:344, 1932. Psaradelis, CSJN, Fallos 171:310, 1934. Hernández, CSJN, Fallos 173:179, 1935. Kaiser, CSJN, Fallos 183:373, 1939. Gagliotti, CSJN, Fallos 188:326, 1940. Rial y Freire, CSJN, Fallos 205:628, 1946. Grunblatt, CSJN, Fallos 210:558, 1948. Cardozo Galeano, CSJN, Fallos 313:101, 1990.

38 Convención Americana sobre Derechos Humanos, art. 22.5.

39 Declaración Americana de Derechos y Deberes del Hombre, art. VIII.

40 Pacto Internacional de Derechos Civiles y Políticos, art. 12.4.

41 Observación General número 15. La situación de los extranjeros con arreglo al Pacto, Comité de Derechos Humanos, 1986. 
ración Universal de Derechos Humanos establece que toda persona tiene derecho a circular libremente y a elegir su residencia en el territorio de un Estado ${ }^{42}$. La literalidad del precepto parecería indicar que si existe la posibilidad de circular y elegir el lugar de residencia en un Estado, existe también un derecho previo a ingresar a ese Estado. Sin embargo, el segundo apartado del mismo artículo se refiere al derecho de toda persona de regresar $a$ su pais $s^{43}$, y resultaría un absurdo que existiera un derecho a ingresar a cualquier país pero a regresar sólo al propio. Y la Asamblea General de las Naciones Unidas, que puede considerarse intérprete autorizada de la Declaración Universal, no ha reconocido tal derecho a ingresar al Estado cuya nacionalidad no se posee ${ }^{44}$.

La Convención Internacional sobre la Protección de los Derechos de Todos los Trabajadores Migratorios y sus Familiares (a partir de ahora, Convención sobre Trabajadores Migratorios), finalmente, consagra el derecho de los trabajadores migratorios y de sus familiares de regresar a su propio pais ${ }^{45}$. Asume, así, la misma perspectiva que la Declaración Universal de Derechos Humanos.

\section{Supuestos de admisión y denegación de entrada}

Dado que no existe, al menos de modo general, un derecho del extranjero, constitucional o internacionalmente reconocido, a ingresar al territorio, el Estado puede establecer en qué supuestos y bajo qué condiciones admite a los extranje$\operatorname{ros}^{46}$. Ahora bien, la discrecionalidad estatal en este punto no es absoluta ya que, como lo han dicho la Corte Interamericana ${ }^{47}$ y la Comisión Interamericana ${ }^{48}$, es

42 Declaración Universal de Derechos Humanos, art. 13.1.

43 Declaración Universal de Derechos Humanos, art. 13.2.

44 Ver, entre muchas otras, Resolución 40/144 sobre los derechos humanos de los individuos que no son nacionales del país en que viven, en especial arts. $2^{\circ}$ y $5^{\circ}$.

45 Convención sobre Trabajadores Migratorios, art. 8.2.

46 Ver la jurisprudencia de la CSJN citada en la nota 38.

47 Condición jurídica y derechos de los migrantes indocumentados, Corte IDH, OC-18/03, serie A No 18 , 2003. Vélez Loor, Corte IDH, serie C No 218, 2010. Nadège Dorzema, Corte IDH, serie C No 251, 2012. Derechos y garantías de niñas y niños en el contexto de la migración y/o en necesidad de protección internacional, Corte IDH, OC-21/14, serie A No 21, 2014. Personas dominicanas y haitianas expulsadas, Corte IDH, serie C No 282, 2014.

48 Entre otros, Riebe Star, Barón Guttlein e Izal Elorz, Comisión IDH, informe 49/99, caso 11610, 1999. 
necesario que el Estado respete los límites impuestos por el derecho internacional (además de los que puedan surgir de la propia Constitución).

En este campo tiene particular relevancia el principio de no discriminación. La Constitución consagra la igualdad ante la ley ${ }^{49}$, pero lo hace sólo para sus habitantes, de manera que los extranjeros que no son habitantes no están amparados por ella. El principio de no discriminación que los instrumentos internacionales consagran ${ }^{50}$ es más amplio no sólo en su letra, sino también en el espíritu que surge de la interpretación que de ellos se ha hecho.

Aunque la nacionalidad no es una de las bases de discriminación prohibida expresamente mencionadas por los tratados, sí lo son el origen nacional, el nacimiento y cualquier otra condición social (esta última categoría, lo suficientemente amplia como para incluir en ella a la nacionalidad). En cualquier caso, la distinción entre nacionales y extranjeros es el fundamento de cualquier política migratoria, y por supuesto no puede afirmarse que esta distinción sea de por sí ilegítima a la luz del derecho internacional. La Corte Interamericana ha aceptado que las distinciones entre nacionales y extranjeros, así como entre diferentes categorías de extranjeros, son legítimas en la medida en que sean proporcionadas, objetivas y razonables ${ }^{51}$.

El principio en esta materia es que, en relación con el derecho a ingresar al territorio, el Estado puede establecer las distinciones que estime necesarias de conformidad con su política migratoria, siempre que ellas no supongan una discriminación prohibida. Claro que es mucho más difícil saber qué supuestos concretos constituyen una discriminación prohibida y qué supuestos son una distinción proporcionada, objetiva y razonable. Por ejemplo, en los años '20 y '30 del siglo XX, la Corte Suprema admitió que era legítimo denegar la entrada al país de personas con determinadas enfermedades contagiosas ${ }^{52}$. Sin perjuicio

49 Constitución de la Nación Argentina, art. 16 (idéntico y con la misma numeración en las versiones de 1853, 1860 y 1994, salvo una ligera variante formal).

50 Declaración Universal de Derechos Humanos, arts. $1^{\circ}$ y $2^{\circ}$; Pacto Internacional de Derechos Civiles y Políticos, arts. $2^{\circ}$ y 26, Convención Americana de Derechos Humanos, arts. $1^{\circ}$ y 24; Declaración Americana de Derechos y Deberes del Hombre, art. II. Convención sobre el Estatuto de los Refugiados, art. $3^{\circ}$. Convención sobre Trabajadores Migratorios, art. $7^{\circ}$.

51 Ver jurisprudencia citada en nota 48.

52 Magaz de González, CSJN, Fallos 148:410, 1926. Se rechazó el habeas corpus en favor de una mujer cuya entrada al país había sido denegada por padecer de tracoma. La Corte consideró que debía aplicarse la prohibición de ingreso establecida en la Ley de Inmigración, pasando totalmente por alto que la mujer ya había residido en el país con anterioridad a su (nuevo) intento de ingreso frustrado. En este sentido, podía 
de las necesarias medidas de salubridad pública que puedan ser adoptadas, una prohibición absoluta como la convalidada por la Corte parece hoy más difícil de sostener.

Todavía más difícil es determinar la legitimidad de las restricciones a la inmigración basadas en criterios económicos. Así, es de interés el preguntarse si un sistema de cuotas migratorias, como el aplicado por muchos países desarrollados, resultaría legítimo. Tal sistema supone que la admisión de extranjeros se hace sobre una determinación previa de las necesidades de mano de obra del mercado local, admitiendo en cada sector de actividad un número limitado de extranjeros en función de lo que se entiende económicamente necesario.

La legitimidad de tales cuotas a la luz del derecho internacional no es dudosa. La propia Corte Interamericana ha señalado que resulta legítimo limitar los permisos de residencia y trabajo al desempeño de determinadas actividades ${ }^{53}$. El mayor escollo podría estar en la disposición constitucional que prohíbe limitar la inmigración ${ }^{54}$. Sin embargo, debe tenerse en cuenta que lo que este artículo prohíbe es restringir la inmigración útil. No parece totalmente desatinado pensar que, en la medida en que esta disposición se basa en la finalidad de promover el desarrollo del país, la aplicación de cuotas migratorias razonables que tiendan a tal fin pueda ser vista como legítima, aunque ciertamente el escrutinio constitucional debería ser estricto.

Hemos dicho en la introducción que la actual Ley de Migraciones ha reconocido en su articulado un derecho humano a migrar ${ }^{55}$. A nuestro juicio tal disposición proporciona un criterio interpretativo aplicable a las condiciones de ingreso y permanencia en el territorio, obligando por ejemplo a interpretar con espíritu generoso los supuestos que habilitan la radicación en el país. Sin embargo, en la medida en que tal disposición tiene jerarquía legal (y no constitucional) y está al mismo nivel que las demás normas de la misma ley

ser considerada un habitante con un derecho constitucionalmente protegido a entrar al territorio nacional. Hernández, CSJN, Fallos 173:179, 1935. Caso de un inmigrante afectado de tracoma que, tras serle denegado el ingreso al país, entra en él de modo irregular. La Corte rechaza el habeas corpus.

53 Condición jurídica y derechos de los migrantes indocumentados, OC-18/03, serie A No 18, Corte IDH, 2003.

54 Constitución de la Nación Argentina, art. 25 (idéntico y con la misma numeración en las versiones de 1853,1860 y 1994).

55 Se ha afirmado que tal derecho legalmente reconocido no sería sólo una declaración de principios, sino que exigiría que toda la política migratoria se ajustara a él. Federación Internacional de Derechos Humanos - Centro de Estudios Legales y Sociales (2011). 
(en materia, por ejemplo, de condiciones e impedimentos de ingreso), ella no puede servir para crear un derecho autónomo a ingresar al territorio allí donde ese derecho no está legal o reglamentariamente reconocido.

No nos detendremos aquí en cada una de las causales de denegación de entrada al territorio establecidas en la actual Ley de Migraciones ${ }^{56}$. Señalaremos sólo algunos puntos de particular relevancia constitucional. Por ejemplo, respecto de la presentación de documentos falsificados o que no reúnen las condiciones legalmente establecidas, se ha llamado adecuadamente la atención sobre la necesidad de que la determinación sobre la veracidad material e ideológica, así como la adecuación a los requisitos técnicos establecidos, sea efectuada por personal idóneo para evitar decisiones arbitrarias ${ }^{57}$.

Otra situación problemática surge de saber quién es competente para determinar que se dan aquellos supuestos de denegación de ingreso por realización de ciertas actividades contrarias al orden público cuando no se requiere una condena penal previa. Por ejemplo, el supuesto de haber sido condenado "por tráfico de armas, de personas, de estupefacientes o por lavado de dinero o inversiones en actividades ilícitas o por delito que merezca para la legislación argentina pena privativa de la libertad de tres años o más" 58 es suficientemente claro. Pero no sucede lo mismo con el impedimento de "promover la prostitución". Ciertamente no se requiere una condena previa, ya que el mismo inciso también dice que es causal de denegación de entrada el "haber sido condenado o tener antecedentes [...] por haber promovido la prostitución”. Pero entonces, ¿quién es competente para determinar que una persona promueve la prostitución?

Hay que mencionar finalmente que los extranjeros que sí son habitantes (porque han sido admitidos en el territorio y han instalado o tienen intención de instalar allí su residencia) están protegidos por el derecho a entrar en el

\footnotetext{
56 Ley No 25.871 (2004), art. 29: presentación de documentos falsificados, prohibición de entrada previamente dictada de acuerdo con la ley, condena previa por ciertos delitos, promoción de la prostitución, intento de entrada de modo de evadir el control migratorio, incumplimiento de los requisitos establecidos en la ley. Ley No 25.871 (2004), art. 35: la documentación de entrada no reúne las condiciones establecidas en la legislación o está adulterada, dudas sobre la realidad de los motivos invocados al momento del control migratorio o de la obtención de la visa. Según ha dicho la Corte, en el ejercicio de sus facultades constitucionales, el Poder Ejecutivo puede reglamentar los supuestos de negativa al ingreso, pero es preciso que la reglamentación dictada esté fundada en ley. Maciá y Gassol, CSJN, Fallos 151:211, 1928.

57 Federación Internacional de Derechos Humanos - Centro de Estudios Legales y Sociales (2011), p. 16.

58 Ley No 25.871 (2004), art. 29.c.
} 
territorio. Así, un extranjero que ha sido admitido en el territorio y ha obtenido un derecho de permanecer en él puede salir del territorio y volver a ingresar sin necesidad de completar nuevamente las formalidades relativas a la primera entrada, a condición de que su permiso de residencia no haya expirado ${ }^{59}$.

\section{Rol de las empresas transportistas}

La Ley de Migraciones prevé sanciones de multa para las empresas de transporte internacional en caso de denegación de entrada de un extranjero transportado por ellas. Según la Corte Suprema (caso Lufthansa), el hecho de imponer una multa a una empresa responsable del transporte de un pasajero que no reúne las condiciones legales requeridas para la entrada en el territorio y el hecho de que esta multa sea proporcional al precio del billete pagado por el pasajero son conformes a la Constitución ${ }^{60}$.

\section{SAlida DE eXtranjeros}

\section{Salida voluntaria}

La libertad de salir del territorio está garantizada en la Constitución a todos los habitantes ${ }^{61}$. Aunque no se siga de una lectura literal de la norma, no parece que haya razones para excluir el derecho de los extranjeros no habitantes a salir del país. En cualquier caso, el derecho a salir de un país (propio o ajeno), está reconocido en instrumentos internacionales con jerarquía constitucional respecto

59 Bertone, CSJN, Fallos 164:290, 1932. Habeas corpus en favor de una persona de nacionalidad italiana, radicada en Argentina y que había vivido durante ocho años en el país, a quien se le deniega la entrada aplicando el régimen legal correspondiente a la primera entrada al país. La Corte hace lugar al habeas corpus. Di Cesare, CSJN, Fallos 184:101, 1939. Habeas corpus concedido en favor de un extranjero radicado en el país que, tras ausentarse por algunos meses, vuelve a ingresar como polizón de un barco. Rodríguez, CSJN, Fallos 197:332, 1943. Habeas corpus resuelto favorablemente en favor de un extranjero que había vivido durante largo tiempo en el país y cuyo reingreso había sido prohibido por sus supuestas ideas comunistas.

60 Lufthansa, CSJN, Fallos 328:2909, 1999.

61 Constitución de la Nación Argentina, art. 14 (idéntico y con la misma numeración en las versiones de 1853,1860 y 1994 , salvo una ligera variante formal). 
de toda persona ${ }^{62}$, así como en otros tratados internacionales sin jerarquía constitucional pero referidos específicamente a la situación de ciertos extranjeros ${ }^{63}$.

La jurisprudencia de la Corte Suprema ha confrontado algunas restricciones indirectas (que pueden afectar tanto a nacionales como a extranjeros), como las que se derivan del poder de policía monetaria. En la sentencia Ventura, la Corte declaró que la decisión del Banco Central que obligaba a quien había comprado un pasaje aéreo en moneda extranjera a pagar la diferencia entre el tipo de cambio al momento de la compra y el tipo de cambio al momento del viaje implicaba un verdadero impuesto a la salida del territorio contrario a la libertad constitucional a salir del país ${ }^{64}$.

\section{Expulsión}

La potestad estatal de expulsar extranjeros, tradicionalmente reconocida por el derecho internacional, ha sido confirmada infinidad de veces por la Corte Suprema de Justicia. El Estado puede excluir del territorio a quienes no son miembros de la comunidad política. "Si es un derecho del Gobierno de la Nación impedir la entrada de extranjeros que no reúnan las condiciones preceptuadas por la Constitución y las leyes reglamentarias, lo es también el de excluirlos de su seno cuando han ingresado al país violando sus disposiciones o cuando después de admitidos resultan peligrosos o indeseables por su conducta o actividades y comprometen con ellas la seguridad del Estado o la paz social"65.

El primer supuesto que habilita la expulsión es, entonces, el del ingreso irregular al país. Desde antaño, la jurisprudencia de la Corte Suprema ha aceptado que quien se encuentra irregularmente en el territorio no puede ser considerado un habitante y, por lo tanto, no puede invocar un derecho constitucionalmente

62 Pacto Internacional de Derechos Civiles y Políticos, art. 12.2; Convención Americana de Derechos Humanos, art. 22.2. Sobre esta cuestión desde la perspectiva del sistema interamericano ver RELATORÍA SOBRE los Derechos de los Migrantes (2015), en especial el capítulo 6.C.

63 Convención sobre el Estatuto de los Refugiados, art. 28. Convención sobre Trabajadores Migratorios, art. $8^{\circ}$. De acuerdo con esta última Convención, además, los Estados deben hacer todo lo posible para autorizar a los trabajadores temporales a ausentarse temporalmente sin que ello afecte su autorización de residencia o permiso de trabajo. Al hacerlo, los Estados deben tener presentes las obligaciones y necesidades de los trabajadores migratorios, e informarlos plenamente de las condiciones en que están autorizadas las ausencias temporales (art. 38).

64 Ventura, CSJN, Fallos 294:152, 1976.

65 Transporte Chaco, CSJN, Fallos 164:344, 1932. 
protegido a permanecer en el territorio. En consecuencia, puede ser legítimamente expulsado ${ }^{66}$. En el caso Maciá y Gassol la Corte fue más rigurosa y dijo que para que la expulsión pudiera tener lugar era necesario que ella estuviera expresamente prevista en la ley como consecuencia del ingreso o permanencia irregular ${ }^{67}$. Aunque la Corte no lo dijo expresamente, es posible que el especial tratamiento del caso se debiera al carácter de asilados políticos de las personas en cuestión ${ }^{68}$. El segundo supuesto de expulsión autorizado por la jurisprudencia constitucional es la expulsión de quienes, aun habiendo ingresado al país de modo regular, han incurrido en alguna causal que habilita su expulsión. Bajo ciertas condiciones, el derecho a permanecer en el territorio puede ser retirado y la expulsión pronunciada en consecuencia. Hay que volver aquí sobre la sentencia clásica de la Corte Suprema sobre la Ley de Residencia (caso Transporte Chaco). Como ya dijimos, la Corte concluyó que esta ley era conforme a la Constitución y sostuvo que los extranjeros habitantes pueden ser expulsados si no respetan las condiciones en las que han sido admitidos, es decir, las condiciones de ejercer una actividad útil y no comprometer el orden público: "los derechos reconocidos por el art. 14 a

66 Psaradelis, CSJN, Fallos 171:310, 1934. Habeas corpus en defensa de un marinero evadido de un barco que ingresó irregularmente al territorio. Rechazado por la Corte. Kaiser, CSJN, Fallos 183:373, 1939. Gagliotti, CSJN, Fallos 188:326, 1940. Rial y Freire, CSJN, Fallos 205:628, 1946. Estos tres últimos casos, idénticos al precedente Psaradelis. Hernández, CSJN, Fallos 173:179, 1935. No procede el habeas corpus en favor de un extranjero cuya entrada se denegó por padecer enfermedad contagiosa y que luego se evadió. Grunblatt, CSJN, Fallos 210:558, 1948. No procede el habeas corpus para impedir la expulsión de quien ha ingresado irregularmente al país.

67 Maciá y Gassol, CSJN, Fallos 151:211, 1928. En el caso, relativo al líder republicano catalán Francisco Maciá y su secretario Ventura Gassol, la Corte concluyó que el decreto del Poder Ejecutivo que exigía como requisito de entrada de cualquier extranjero la presentación de un certificado de antecedentes penales visado por el cónsul argentino en el país de origen era constitucional. El Poder Ejecutivo se había mantenido dentro de sus facultades constitucionales porque tal decreto había sido dictado al amparo no sólo de la Ley de Inmigración (que no se refería a todo extranjero sino sólo a los inmigrantes), sino también de la Ley de Residencia (que permitía la denegación de entrada a cualquier extranjero que se hallara comprendido en los términos de sus cláusulas). Sin embargo, el Poder Ejecutivo, alegando ese decreto, había procedido a expulsar a los extranjeros (y no simplemente a denegarles la entrada). Maciá y Gassol habían vuelto a ingresar clandestinamente al país (es decir, nuevamente sin presentar su certificado de antecedentes) y temían una nueva expulsión. La Corte otorgó la protección del habeas corpus señalando que la expulsión previa había sido ilegal (porque no se daban a su respecto ninguno de los supuestos de la Ley de Residencia que autorizaban la expulsión) y que mientras no se diera alguno de esos supuestos los extranjeros estaban amparados por el derecho de todo habitante a permanecer en el país.

68 Esta es la interpretación realizada por el Procurador Fiscal y por la propia Corte Suprema, al citar el precedente Maciá y Gassol en un caso posterior. Ver dictamen del Procurador fiscal y sentencia de la Corte en Hernández, CSJN, Fallos 173:179, 1935. 
los extranjeros han de entenderse subordinados a la regla del art. 25 que también forma parte del sistema adoptado por la Constitución en esta materia, y, consiguientemente, a las leyes dictadas por el Congreso en consonancia con ella. Y la naturaleza de esta conclusión descarta toda argumentación de inconstitucional fundada en el art. 16, pues la igualdad que éste preconiza se realiza respecto de todos los habitantes nacionales y extranjeros pero siempre que estos últimos observen las condiciones en que fueron admitidos"69.

La consideración acerca de cuáles son los aspectos sustantivos que pueden habilitar la expulsión del extranjero ha variado a lo largo del tiempo. En cualquier caso, la Corte ha sido consistente en afirmar que la expulsión sólo puede ordenarse por autoridad competente en ejercicio de funciones encomendadas por la ley. En un caso pionero en el campo, la Corte protegió a un grupo de extranjeros de etnia gitana que habían sido expulsados por una autoridad incompetente y sin ningún tipo de base legal (Pedro Miguel, Esteban Juan y $\operatorname{otros}^{70}$ ). Con posterioridad la Corte insistió sobre la necesidad de respetar el principio de legalidad, no sólo respecto de la competencia de la autoridad que ordena la expulsión sino también en lo que se refiere a la definición de la causal que la habilita ${ }^{71}$.

La perspectiva de la jurisprudencia interna se ve reforzada por los tratados internacionales de derechos humanos. La Convención Americana explicita el principio de legalidad en relación con la expulsión, aunque solamente para los extranjeros cuya presencia en el territorio es regular ${ }^{72}$. El mismo criterio aparece en el Pacto Internacional de Derechos Civiles y Políticos ${ }^{73}$. Sin embargo, y a pesar del texto de la Convención Americana, la Corte Interamericana ha aplicado esta

69 Transporte Chaco, CSJN, Fallos 164:344, 1932.

70 Pedro Miguel, Esteban Juan y otros, CSJN, Fallos 117:165, 1913. Se hace lugar al habeas corpus interpuesto en favor de un grupo de gitanos que habían residido durante más de veinte años en la República y que, tras salir del país y volver a ingresar desde Chile, fueron detenidos en vistas a su expulsión. El departamento de inmigración carecía de autoridad para ordenar tal expulsión (sólo podía aconsejar medidas y, en cualquier caso, solamente en relación con las personas que cayeran dentro de la definición de inmigrantes según la Ley No 817 , que no era el caso).

71 Carrizo Coito, CSJN, Fallos 302:604, 1980. La Corte hace lugar al amparo promovido por una persona que iba a ser expulsada en razón de sus creencias religiosas. Cardozo Galeano, CSJN, Fallos 313:101, 1990. Se rechaza un amparo contra una decisión de la Dirección de Migraciones que deniega un permiso de residencia porque tal denegación estaba basada en ley.

72 Convención Americana sobre Derechos Humanos, art. 22.6. Ver Relatoría sobre los Derechos de los Migrantes (2015), en especial el capítulo 7.

73 Pacto Internacional de Derechos Civiles y Políticos, art. 13. El Relator Especial de las Naciones Unidas sobre Expulsión de Extranjeros ha realizado una labor de recopilación y análisis de normas internacionales 
garantía a todos los extranjeros, incluso a aquéllos que están presentes de modo irregular en el territorio. Incluso a su respecto, la expulsión debe pronunciarse de conformidad con la ley ${ }^{74}$. Esta extensión de garantías obliga a corregir la corriente dominante en la jurisprudencia de la Corte Suprema que habilitaba cierta flexibilidad en la expulsión de quien había ingresado de modo irregular al territorio (entre otras cosas, porque no podía ser considerado habitante de conformidad con la jurisprudencia clásica). La Corte Interamericana también ha afirmado que el principio de no discriminación se aplica particularmente a los procedimientos de expulsión 75 .

La Corte Interamericana también ha sostenido que toda la actividad sancionadora en el marco de la normativa migratoria está limitada por el principio de legalidad de la Convención Americana ${ }^{76}$ (esto incluye, por ejemplo, la aplicación de multas u otras sanciones por infracción de la normativa migratoria). Sin embargo, la privación de libertad con carácter punitivo en razón de infracciones a normas migratorias resulta contraria a la Convención, ya que supera el legítimo interés del Estado en realizar un efectivo control migratorio (como veremos más abajo, en algunos casos la privación de libertad puede aplicarse de modo cautelar, para garantizar los fines del procedimiento migratorio; pero nunca como sanción) $)^{77}$.

La Convención sobre el Estatuto de los Refugiados prohíbe expulsar a un refugiado que se halle legalmente en el territorio del Estado salvo por razones de seguridad nacional o de orden público, debiendo hacerse la expulsión, en tal caso, siempre conforme a la legalidad vigente ${ }^{78}$. Y contiene, además, el conocido principio de non-refoulement, según el cual un refugiado no puede ser puesto en las fronteras de un Estado donde su vida o su libertad peligren por causa de su

y nacionales sobre la expulsión de extranjeros. Ver Камто (2005), Камто (2006), Камто (207), Камто (2008), Камто (2009), Камто (2010), Камто (2011), Камто (2012).

74 Vélez Loor, Corte IDH, serie C No 218, 2010. Nadège Dorzema, Corte IDH, serie C No 251, 2012. Personas dominicanas y haitianas expulsadas, Corte IDH, serie C No 282, 2014.

75 Vélez Loor, Corte IDH, serie C No 218, 2010. Nadège Dorzema, Corte IDH, serie C No 251, 2012. Personas dominicanas y haitianas expulsadas, Corte IDH, serie C No 282, 2014.

76 Convención Americana sobre Derechos Humanos, art. $9^{\circ}$.

77 Vélez Loor, Corte IDH, 2010.

78 Convención sobre el Estatuto de los Refugiados, arts. 32.1 y 32.2. 
raza, religión, nacionalidad, pertenencia a determinado grupo social u opiniones políticas $^{79}$.

Por otra parte, la Convención sobre Trabajadores Migratorios dispone que los trabajadores migratorios y sus familiares, en situación regular o irregular, sólo pueden ser expulsados en cumplimiento de una decisión adoptada por la autoridad competente conforme a la ley ${ }^{80}$. Ningún trabajador migratorio ni familiar suyo puede ser expulsado por no cumplir una obligación emanada de un contrato de trabajo, salvo que el cumplimiento de esa obligación constituya condición necesaria para su autorización de residencia o permiso de trabajo ${ }^{81}$.

Si la expulsión es ejecutada y luego revocada, el interesado tiene derecho a reclamar indemnización conforme a la ley y no se le puede hacer valer la decisión anterior para impedirle que vuelva a ingresar en el Estado ${ }^{82}$. La expulsión no debe menoscabar los derechos adquiridos de conformidad con la legislación, incluido el derecho a recibir los salarios y otras prestaciones que se le adeuden ${ }^{83}$.

En el caso de trabajadores migratorios y familiares suyos que estén en situación regular se exige, además, que las razones de la expulsión estén definidas en la legislación nacional ${ }^{84}$. La Convención prohíbe también que se expulse a un trabajador o familiar suyo en situación regular con la finalidad de privarlo de los derechos emanados de la autorización de residencia y del permiso de trabajo ${ }^{85}$. Al momento de la expulsión de un trabajador migratorio o familiar suyo en situación regular, el Estado tiene que tomar en cuenta las eventuales consideraciones de carácter humanitario y el tiempo que esa persona lleve residiendo en el Estado ${ }^{86}$.

La aceptación o el rechazo, sobre bases constitucionales, de determinados motivos de expulsión han dependido de las variables circunstancias políticas de cada época. A principios del siglo XX, impregnada del ideario del defensismo

\footnotetext{
constituya una amenaza para la comunidad de tal país (art. 33.2).

80 Convención sobre Trabajadores Migratorios, art. 22.2.

81 Convención sobre Trabajadores Migratorios, art. 20.2.

82 Convención sobre Trabajadores Migratorios, art. 20.5.

83 Convención sobre Trabajadores Migratorios, art. 20.9.

84 Convención sobre Trabajadores Migratorios, art. 56.3.

85 Convención sobre Trabajadores Migratorios, art. 56.3.

86 Convención sobre Trabajadores Migratorios, art. 56.3.
}

79 Convención sobre el Estatuto de los Refugiados, art. 33.1. Sin embargo, no puede invocar el principio el refugiado que sea considerado, por razones fundadas, como un peligro para la seguridad del país donde se encuentra o que, habiendo sido objeto de una condena definitiva por un delito particularmente grave, 
social, la Corte Suprema argentina convalidó la constitucionalidad de la Ley de Residencia reconociendo el derecho del Estado de expulsar a los extranjeros peligrosos o indeseables. Según la Corte de entonces, el extranjero que pone en peligro la seguridad del Estado no puede invocar un derecho constitucional a permanecer en el país, incluso si es un habitante. Este derecho está sometido a la reglamentación de las leyes y es legítimo que la ley condicione la permanencia en el país al respeto del orden social ${ }^{87}$.

La sentencia Transporte Chaco, a pesar de evaluar la legitimidad constitucional de la Ley de Residencia de un modo que hoy nos parecería sumamente laxo, tiene el mérito de entrar a considerar las razones de fondo invocadas por el Poder Ejecutivo (con base en una autorización legislativa) para ordenar la expulsión. A fines de los años '50, en cambio, algunos fallos evidencian un criterio mucho menos protectorio, según el cual la evaluación de las situaciones que autorizan la expulsión de un extranjero es una actividad discrecional del Poder Ejecutivo. Según este criterio, los tribunales deberían limitarse a analizar la nacionalidad de la persona expulsada (para evitar la expulsión de un argentino) y a verificar el respeto de ciertas garantías procedimentales mínimas ${ }^{88}$.

En los años '60 se hace evidente en las sentencias de la Corte una preocupación por las cuestiones de seguridad nacional. La Corte acepta el principio de que es posible expulsar a quienes representen un peligro para la estabilidad de las instituciones del momento, aunque en algunos casos proteja los derechos de los extranjeros por considerar que no se ha acreditado que tal peligro existiera en el caso concreto. Los dictámenes del Procurador Fiscal (que en general aconsejan desestimar las pretensiones de los extranjeros recurrentes) admiten con gran amplitud la discrecionalidad administrativa para expulsar extranjeros vinculados a presuntas actividades subversivas. Un ejemplo en el siguiente fragmento: "al respecto debe considerarse [...] que la sutileza y eficacia de las modernas técnicas de penetración ideológica autorizan ciertamente a interpretar con alguna extensión mayor que la que pudo tradicionalmente ser aceptada, las facultades del Gobierno inherentes a la soberana atribución de defensa nacional que le ha sido siempre reconocida" 89 .

87 Transporte Chaco, CSJN, Fallos 164:344, 1932.

88 Zovrko, CSJN, Fallos 218:490, 1950. Mizzau, CSJN, Fallos 230:252, 1954. En ambos casos se trataba de personas expulsadas en virtud de la Ley de Residencia y la Corte rechazó el habeas corpus.

89 Dictamen del Procurador Fiscal en Argüello Argüello, CSJN, Fallos 268:393, 1967. 
No dejan de ser curiosas, sin embargo, algunas de las circunstancias que la Corte tiene en cuenta para considerar que los extranjeros sujetos a expulsión no representan un peligro subversivo. Por ejemplo, en Argüello Argüello, además de considerar que el extranjero "ha cursado regularmente sus estudios universitarios y terminado su carrera en tiempo normal" y que "no tiene antecedentes de procesos judiciales ni de haber sido nunca detenido ni interrogado sobre sus actividades por los organismos de seguridad", toma en consideración el insólito hecho de que "declaró ser de religión católica" y "ha probado su matrimonio religioso y el bautismo de sus dos hijos" 90 .

Esta última circunstancia contrasta con el hecho de que la Corte rechazara, unos años más tarde, que la religión sea un motivo legítimo de expulsión del territorio $^{91}$. Y si de motivos dudosamente constitucionales se trata, no puede dejar de mencionarse el decreto que declaraba que estaban inhabilitados para permanecer en el país aquellos extranjeros respecto de los cuales se pudiera presumir que "se trata de una persona inútil por carecer de arte, industria, oficio, profesión u otro medio de vida lícito, o por observar una conducta proclive al delito que ofenda a la moral o las buenas costumbres públicas, o por cualquier otra circunstancia que a juicio del Ministerio del Interior lo señale como de dudosa capacidad para integrarse a la sociedad"92. La amplitud del precepto que autorizaba la potestad administrativa de expulsión era dudosamente compatible con la prohibición constitucional de la arbitrariedad ${ }^{93}$.

\section{Aspectos procesales}

La ya varias veces nombrada sentencia Transporte Chaco afirmó que el hecho de que la Ley de Residencia fuera en sí misma constitucional no implicaba que

\footnotetext{
90 Argüello Argüello, CSJN, Fallos 268:393, 1967. Al señor Argüello le es denegado su permiso de radicación permanente y se ordena su expulsión por presuntas actividades subversivas. La Corte concede el amparo en su favor. Ver un caso similar en Britez, CSJN, Fallos 268:406, 1967. La Corte hizo nuevamente lugar al amparo, por considerar que no estaban probadas las actividades subversivas.

91 Carrizo Coito, CSJN, Fallos 302:604, 1980. Caso relativo a un extranjero perteneciente al grupo de los Testigos de Jehová, expulsado del país por esta razón. La Corte hace lugar al amparo.

92 Decreto No 1.023/94, art. 21.g.

93 La propia Dirección de Migraciones se allanó en un proceso en el que había sido planteada tal inconstitucionalidad. Benitez Alicia y otros cl Estado Nacional, Ministerio del Interior, Dirección Nacional de Migraciones slamparo, Juzgado Nacional en lo Contencioso Administrativo Federal, 2003. Sobre las causales de expulsión en la actual ley de migraciones, ver GUASTi (2014).
} 
la expulsión del extranjero pudiera hacerse de cualquier modo. Según la Corte, tres garantías básicas debían ser respetadas: 1) la notificación de la expulsión y sus causas; 2) el derecho de ser oído por la autoridad administrativa; 3) el control judicial del procedimiento y de la sustancia de la decisión de expulsión. Esta última garantía resulta fundamental, ya que aunque la Corte confía en que las facultades del Poder Ejecutivo en el contexto de la mencionada ley sean ejercidas "con las garantías de publicidad y justicia propias de los pueblos libres", en los casos en que esto no fuera así "los jueces estarían facultados para revisar el procedimiento con el fin de impedir que un ciudadano argentino fuese excluido de su país o que un extranjero deseable [es decir, un extranjero que no resulta peligroso en los términos de la Ley de Residencia] fuese injustamente expulsado"94.

La exigencia de ciertas garantías procedimentales mínimas ha sido reiterada en innumerables ocasiones por la Corte ${ }^{95}$. Desde antaño la Corte Suprema ha aceptado que la acción de habeas corpus era adecuada para proteger a un extranjero contra una expulsión ilegal o arbitraria, incluso bajo el estado de sitio $^{96}$. El habeas corpus puede ser utilizado también para hacer frente a una amenaza de expulsión que todavía no se ha concretado en una decisión de la autoridad administrativa ${ }^{97}$.

Sin embargo, la Corte no ha sacado siempre las mejores conclusiones de los principios que ella misma enunciaba. En el caso De la Torre, denegó un habeas

94 Transporte Chaco, CSJN, Fallos 164:344, 1932. Los mismos criterios enunciados en Ordinanz, CSJN, Fallos 215:161, 1949.

95 Doregger, CSJN, Fallos 203:256, 1945. El caso se refería a dos personas (padre e hijo) expulsadas del país por las supuestas gestiones que un familiar habría dirigido a un industrial del exterior. La Corte hace suyos los argumentos de la sentencia de Cámara (favorable a los extranjeros y recurrida por el Ministerio Fiscal) según la cual el derecho de defensa del art. 18 de la Constitución debe ser garantizado incluso en el contexto de la Ley de Residencia. La Corte ordena al Poder Ejecutivo permitir el reingreso al país de los expulsados. Watjen, CSJN, Fallos 204:571, 1946. Habeas corpus relativo a un extranjero que el Poder Ejecutivo había detenido y pretendía expulsar con base en la Ley de Residencia. La Corte entendió que el trámite había sido irregular porque no se había dado al extranjero la posibilidad de conocer los motivos de la expulsión y ser oído en relación con ellos. En consecuencia, ordenó poner en libertad a Watjen. Barwins, CSJN, Fallos 212:101, 1948. La Corte declara que no hay violación de garantías constitucionales en un procedimiento de expulsión si los extranjeros han sido notificados de la orden de expulsión y han tenido un plazo razonable para exponer las razones que se oponían a tal expulsión. Zovrko, CSJN, Fallos 218:490, 1950. Mizzau, CSJN, Fallos 230:252, 1954. Incluso en estos dos últimos casos, en los que la Corte admitió la discrecionalidad del Poder Ejecutivo en la evaluación de las circunstancias que autorizan la expulsión (ver más arriba), se aceptó que eran de aplicación las garantías procesales.

${ }^{6}$ Doregger, CSJN, Fallos 203:256, 1945. Watjen, CSJN, Fallos 204:571, 1946.

97 Maciá y Gassol, CSJN, Fallos 151:211, 1928. 
corpus contra una decisión de expulsión porque al momento en que la causa llegó a sus estrados el extranjero ya había sido expulsado. La Corte entendió, entonces, que había cesado ya la afectación a la libertad ${ }^{98}$. Los votos disidentes de cuatro jueces admitieron, en cambio, que "la expulsión de un extranjero sin que se haya garantizado la posibilidad de acceso a un tribunal judicial, podría no sólo ser contraria al derecho interno sino también al derecho internacional"99 y que la Corte Suprema "ha admitido desde antiguo el control jurisdiccional a la expulsión dispuesta por el Poder Ejecutivo"100. La decisión de la mayoría no sólo contradecía los precedentes de la propia Corte ${ }^{101}$ sino que también, como lo pusieron de manifiesto los votos disidentes, implicaba desconocer que continuaba existiendo gravamen actual a la libertad ambulatoria, en la medida en que pesaba sobre el expulsado una prohibición de reingresar al territorio argentino. Este caso motivó una denuncia contra la Argentina ante la Comisión Interamericana de Derechos Humanos. El procedimiento culminó con un acuerdo amistoso por el cual el Estado se comprometía a revisar la legislación vigente ${ }^{102}$.

La actual Ley de Migraciones prevé que si la Dirección Nacional de Migraciones constata el carácter irregular de la presencia de un extranjero en el territorio debe intimar al extranjero a regularizar su situación en un plazo perentorio que ella misma fijará y si en ese plazo la situación del extranjero no está regularizada ordenar su expulsión del territorio. La orden de expulsión, sin embargo, tiene carácter suspensivo y la Dirección Nacional de Migraciones debe ponerla en conocimiento del juez para que la revise ${ }^{103}$. Según la jurisprudencia de la Corte Suprema, la decisión del juez de primera instancia que revisa la decisión administrativa de expulsión es susceptible de recurso ante la Cámara de Apelaciones correspondiente. Esta segunda instancia es una garantía legal, pero no una ga-

98 De la Torre, CSJN, Fallos 321:3646, 1998. Se trataba de una persona de nacionalidad uruguaya privada de su libertad en vistas a su expulsión y finalmente expulsada.

99 De la Torre, CSJN, Fallos 321:3646, 1998, voto en disidencia de los jueces Fayt, Petracchi y Boggiano.

100 De la Torre, CSJN, Fallos 321:3646, 1998, voto en disidencia del juez Bossert.

101 Doregger, CSJN, Fallos 203:256, 1945. En el caso se admitió el habeas corpus incluso respecto de una decisión de expulsión ya ejecutada.

102 De la Torre, Comisión IDH, informe 85/11, caso 12306, 2011.

103 Ley No 25.871 (2004), art. 61. 
rantía constitucional ${ }^{104}$. La defensa jurídica gratuita debe ser garantizada en caso de expulsión ${ }^{105}$.

El derecho internacional de los derechos humanos refuerza las garantías tradicionalmente aceptadas en materia de expulsión de extranjeros. El Pacto Internacional de Derechos Civiles y Políticos contiene algunas garantías de procedimiento: derecho de exponer las razones que se oponen a la expulsión, derecho de hacer revisar la decisión por las autoridades competentes y de hacerse representar a este efecto $^{106}$. No obstante, estas garantías están previstas solamente para los extranjeros cuya estancia en el territorio es regular y pueden tornarse inaplicables por razones de seguridad nacional ${ }^{107}$. La Convención sobre el Estatuto de los Refugiados contiene una enumeración de garantías procedimentales casi idéntica (derecho a presentar pruebas exculpatorias, a formular recurso de apelación y hacerse representar ante las autoridades o antes las personas designadas por ella). También en este caso las garantías sólo benefician a los refugiados en situación regular y pueden tornarse inaplicables por razones de seguridad nacional ${ }^{108}$. La Convención agrega que, en caso de expulsión, los refugiados han de tener un plazo razonable para gestionar su admisión en otro país, aunque durante ese tiempo los Estados se reservan el derecho de aplicar las medidas de orden interior que consideren necesarias ${ }^{109}$.

La Convención Americana, en cambio, no contiene expresamente en su articulado garantías de procedimiento para las expulsiones. Sin embargo, la Corte Interamericana ha desarrollado algunas de ellas a partir de una lectura sistemática de la propia Convención. Todos los migrantes, con independencia de su estatus migratorio, gozan de la protección del principio de no discriminación y de las garantías del debido proceso ${ }^{110}$. Estas garantías han sido especificadas como sigue $^{111}:$ 1) el derecho a ser informado de los motivos de la expulsión ${ }^{112}$;2) el

\footnotetext{
104 Ojeda Hernández, CSJN, O. 113. XLVIII. RHE, 2014.

105 Ley No 25.871 (2004), art. 86.

106 Pacto Internacional de Derechos Civiles y Políticos, art. 13.

107 Ver Arlettaz (2016a).

108 Convención sobre el Estatuto de los Refugiados, art. 32.2.

109 Convención sobre el Estatuto de los Refugiados, art. 32.3.

110 Condición juridica y derechos de los migrantes indocumentados, Corte IDH, OC-18/03, serie A No 18, 2003.

111 Vélez Loor, Corte IDH, serie C No 218, 2010. Nadège Dorzema, Corte IDH, serie C No 251, 2012.

Personas dominicanas y haitianas expulsadas, Corte IDH, serie C No 282, 2014.

112 Sobre este punto ver también Stetter, Comisión IDH, informe 30/81, caso 7378, 1981.
} 
derecho a la notificación regular de la decisión de expulsión; 3) el derecho a un recurso ante la autoridad competente ${ }^{113}$. En algunos casos, además, otras garantías pueden tornarse aplicables: 1) el derecho a la asistencia consular ${ }^{114}$; 2) el derecho a la asistencia letrada ${ }^{115}$.

La Convención sobre Trabajadores Migratorios es muy detallada en cuanto a las garantías procesales. Exige que la expulsión se comunique en un idioma que los interesados puedan entender (por escrito si lo solicitasen y ello no fuese obligatorio por otro concepto) y que se indiquen, salvo en circunstancias excepcionales justificadas por razones de seguridad nacional, los motivos de la decisión; además, debe informarse a los interesados de estos derechos antes de que se pronuncie la decisión o, a más tardar, en ese momento ${ }^{116}$. Los interesados tienen derecho a exponer sus razones para oponerse a su expulsión, salvo cuando una autoridad judicial haya dictado una decisión definitiva, y a someter su caso a revisión, a menos que razones imperiosas de seguridad nacional se opongan a ello; hasta tanto se haga dicha revisión, tienen derecho a solicitar que se suspenda la ejecución de la expulsión ${ }^{117}$. El interesado debe tener una oportunidad razonable para arreglar lo concerniente al pago de los salarios y otras prestaciones que se le adeuden y al cumplimiento de sus obligaciones pendientes ${ }^{118}$. El interesado tiene el derecho a

113 Sobre este punto ver también Joseph, Comisión IDH, informe 27/93, caso 11092, 1993.

114 Resultan aquí de aplicación las garantías previstas en la Convención de Viena sobre Relaciones Consulares. La Convención establece, por un lado, un derecho genérico de las personas a comunicarse con las autoridades consulares de su país e, inversamente, el derecho de estas autoridades a comunicarse con sus nacionales (artículo 36.1.a). Por otro lado, establece una serie de derechos particulares en caso de privación de libertad. Estos derechos son (artículo 36.1.b): el derecho a la notificación de la oficina consular de la situación de privación de libertad de uno de sus nacionales; el derecho de comunicación sin demora con la oficina consular; el derecho de la persona a ser informada de que tiene estos derechos. Estas garantías fueron objeto de una opinión consultiva específica de la Corte Interamericana: El derecho a la asistencia consular en el marco de las garantías del debido proceso legal, Corte IDH, 1999.

115 En relación con el derecho a la asistencia letrada, la Corte Interamericana parece señalar como indispensable la garantía de la asistencia jurídica gratuita en aquellos casos en los que la consecuencia del procedimiento migratorio pueda ser una privación de la libertad. Vélez Loor, Corte IDH, serie C No 218, 2010. Nadège Dorzema, Corte IDH, serie C No 251, 2012. La Comisión, en cambio, parece mencionarla como una garantía debida en todo procedimiento de expulsión. Riebe Star, Barón Guttlein e Izal Elorz, Comisión IDH, informe 49/99, caso 11610, 1999. Sobre las garantías procesales en caso de expulsión desde la perspectiva del sistema interamericano ver Relatoría sobre los Derechos de los Migrantes (2015), en especial el capítulo 7.

116 Convención sobre Trabajadores Migratorios, art. 20.3.

117 Convención sobre Trabajadores Migratorios, art. 20.4.

118 Convención sobre Trabajadores Migratorios, art. 20.6. 
solicitar la autorización de ingreso a un Estado que no sea el de su origen ${ }^{119}$. Los gastos de la expulsión no deben correr por cuenta del expulsado, aunque puede exigírsele que pague sus propios gastos de viaje ${ }^{120}$. El interesado tiene derecho a recurrir a la protección y asistencia de las autoridades consulares y debe ser informado de este derecho ${ }^{121}$.

Otro elemento importante a considerar en relación con las garantías procedimentales es la prohibición de las expulsiones colectivas. El derecho internacional prohíbe la expulsión colectiva de extranjeros ${ }^{122}$. Según la Corte Interamericana, una expulsión es colectiva si no se considera la situación particular de cada persona expulsada ${ }^{123}$. La prohibición de expulsión colectiva está expresamente receptada en la Ley de Migraciones ${ }^{124}$.

\section{Protección de la UnidAd FAMILIAR}

El art. 14 bis de la Constitución dispone, de modo programático, que la ley debe establecer "la protección integral de la familia"125. Muchos documentos internacionales con jerarquía constitucional insisten en este punto. Según la Declaración Universal de los Derechos Humanos, "la familia es el elemento natural y fundamental de la sociedad y tiene derecho a la protección de la sociedad y del Estado"126. El Pacto Internacional de Derechos Civiles y Políticos establece que nadie puede ser objeto de injerencias arbitrarias en su vida familiar ${ }^{127}$ y reproduce luego la disposición recién transcrita de la Declaración Universal ${ }^{128}$. De acuerdo con el Pacto Internacional de Derechos Económicos, Sociales y Culturales,

119 Convención sobre Trabajadores Migratorios, art. 20.7.

120 Convención sobre Trabajadores Migratorios, art. 20.8.

121 Convención sobre Trabajadores Migratorios, art. 23.

122 Convención Americana sobre Derechos Humanos, art. 22.9. Convención sobre Trabajadores Migratorios, art. 22.1 .

123 Corte IDH, Nadège Dorzema, serie C no. 251, 2012. Corte IDH, Personas dominicanas y haitianas expulsadas, serie C No 282, 2014. Sobre las expulsiones colectivas desde la perspectiva del sistema interamericano ver Relatoría sobre los Derechos de los Migrantes (2015), en especial el capítulo 6.E.

124 Ley No 25.871 (2004), art. 66.

125 Constitución de la Nación Argentina según la reforma de 1957, art. 14 bis.

126 Declaración Universal de los Derechos Humanos, art. 16.

127 Pacto Internacional de Derechos Civiles y Políticos, art. 17.

128 Pacto Internacional de Derechos Civiles y Políticos, art. 23. 
"se debe conceder a la familia, que es el elemento natural y fundamental de la sociedad, la más amplia protección y asistencia posibles, especialmente para su constitución y mientras sea responsable del cuidado y la educación de los hijos a su cargo"129. La Convención Americana de Derechos Humanos dice que "la familia es el elemento natural y fundamental de la sociedad y debe ser protegida por la sociedad y el Estado"130. La Convención sobre los Derechos del Niño es mucho más específica, al establecer que el niño tiene derecho a "vivir con su padre y su madre, excepto en los casos que la separación sea necesaria para su interés superior" y a "mantener contacto directo con ambos, si está separado de uno de ellos o de los dos"131. Además, el Estado debe "responsabilizarse de este aspecto, en el caso de que la separación haya sido producida por acción del mismo"132. Igualmente, "es derecho de los niños y sus padres y madres salir de cualquier país y entrar en el propio, con miras a la reunificación familiar o el mantenimiento de la relación entre unos y otros"133. La Convención sobre Trabajadores Migratorios también dispone que la familia "es el grupo básico natural y fundamental de la sociedad" y que tiene derecho "a protección por parte de la sociedad y del Estado"134.

El criterio de unidad familiar puede ser fuente de un derecho de ingresar y permanecer en el territorio argentino. Una legislación sobre migraciones que no previera ningún mecanismo de reunificación para los familiares de argentinos o para los familiares de los extranjeros radicados en el país sería sin dudas violatoria de los preceptos reseñados. Mucho más difícil, sin embargo, es saber hasta qué punto se extiende la obligación del Estado de permitir la reunificación. Es indudable que, como mínimo, se debe garantizar la reunificación del cónyuge y de los hijos menores. Pero más allá la cuestión deviene más dudosa. ¿Está el Estado obligado a permitir la reunificación de las parejas no casadas? ¿De los hijos mayores pero dependientes? ¿De otros descendientes que no sean hijos (nietos, por ejemplo)? ¿De los descendientes del cónyuge? ¿De los ascendientes?

La Convención sobre Trabajadores Migratorios dispone que los Estados deben adoptar las medidas apropiadas para facilitar la reunión de los trabajadores

129 Pacto Internacional de Derechos Económicos, Sociales y Culturales, art. 10.

130 Convención Americana sobre Derechos Humanos, art. 17.

131 Convención sobre los Derechos del Niño, art. $9^{\circ}$.

132 Convención sobre los Derechos del Niño, art. 9º

133 Convención sobre los Derechos del Niño, art. 10.

134 Convención sobre Trabajadores Migratorios, art. 44.1. 
migratorios con sus cónyuges o con aquellas personas con las que mantengan una relación que, de conformidad con el derecho aplicable, produzca efectos equivalentes al matrimonio, al igual que con sus hijos solteros menores de edad a su cargo ${ }^{135}$. Los Estados deben considerar favorablemente conceder el mismo trato a otros familiares, por razones humanitarias ${ }^{136}$.

La Ley de Migraciones establece que uno de los objetivos de la ley es "garantizar el ejercicio del derecho a la reunificación familiar"137, que ella regula con un criterio amplio. La Corte Suprema se pronunció una vez en relación con la unificación familiar, aunque enfocando cuestiones de legalidad y no cuestiones constitucionales (caso Zhang). Allí señaló "la importancia que en la nueva ley reviste el principio de unidad familiar en materia de inmigración”. El Tribunal también hizo suyas las expresiones del demandado que, allanándose a la pretensión, dijo que hacer prevalecer los impedimentos legalmente previstos para obtener un permiso de ingreso y residencia en el país por sobre el principio de unificación familiar implicaría "frustrar la reunificación familiar, con sus secuelas de daño irreparable para todos sus integrantes por la eventual responsabilidad de uno de sus miembros" 138 .

No está claro cuál es el alcance exacto de esta última afirmación que, si fuera tomada en toda su extensión, implicaría que el régimen legal de impedimentos al ingreso y permanencia en el país no resultaría aplicable cuando el ingreso y la permanencia pretenden basarse en el criterio de unificación familiar. Este criterio extenso no es recogido por la Ley de Migraciones, que no dispone la inaplicabilidad del régimen de impedimentos aunque sí permite que la Dirección Nacional de Migraciones, de modo fundado, admita excepcionalmente por razones huma-

135 Convención sobre Trabajadores Migratorios, art. 44.2.

136 Convención sobre Trabajadores Migratorios, art. 44.3.

137 Ley No 25.871 (2004), art. 3º.d.

138 Zhang, CSJN, Fallos 330:4554, 2007. El caso era relativo a la esposa y el hijo de un nacional chino radicado en Argentina. La Dirección Nacional de Migraciones expidió el correspondiente permiso de ingreso pero, al solicitar a continuación el visado en el consulado argentino en Pekín, se descubrió un aparente intento de soborno a un funcionario consular por parte de la esposa. El visado fue denegado sobre la base del art. 21.g del entonces vigente decreto 1023/94, que declaraba inhábil para la residencia permanente a las personas que tuvieran una "conducta proclive al delito". Al momento de fallar la Corte Suprema, la antigua legislación migratoria había sido reemplazada por la Ley No 25.871. La Corte hizo lugar al amparo sobre la base de que la nueva ley había eliminado la inhabilidad por proclividad al delito y de que tenía un espíritu mucho más generoso en materia de reunificación familiar. En consecuencia, ordenó que se dictara una nueva sentencia por parte del tribunal de origen. 
nitarias o de reunificación familiar a personas comprendidas en algunos de los impedimentos ${ }^{139}$. El criterio extenso de exclusión del régimen de impedimentos en los casos de reunificación familiar tampoco viene constitucionalmente exigido, porque aunque la protección de la familia sea un principio constitucional, una reglamentación razonable de este principio puede incluir ciertas excepciones basadas, por ejemplo, en criterios de orden público. En otras palabras, la Constitución no exige que siempre la unidad de la familia prevalezca sobre los impedimentos al ingreso y permanencia en el país.

Si la unidad familiar puede verse afectada por los criterios de admisión al territorio, también puede serlo por la aplicación de una medida de expulsión. Lo dicho en el párrafo anterior es también aplicable a este supuesto: aunque el Estado está obligado constitucionalmente a proteger la unidad familiar, esto no quiere decir que una expulsión que quiebra esa unidad sea siempre inconstitucional por ese solo hecho. Dicho de otro modo, la Constitución no exige que el Estado se abstenga de expulsar a una persona en todos los casos en los que esa expulsión rompería la unidad familiar; si así fuera, no sería posible expulsar a ningún extranjero con vínculos familiares en el territorio.

Un aspecto particular de la unidad familiar es el relativo a la protección de los menores. La Corte Interamericana ha dicho repetidamente que cuando un Estado adopta una decisión que involucra derechos de menores debe tener en cuenta su superior interés ${ }^{140}$. Esto es aplicable también en materia migratoria: en las decisiones sobre admisión o expulsión de extranjeros, los Estados deben tener en cuenta el efecto que ellas puedan tener en lo relativo a la separación del menor y sus progenitores.

La Corte Interamericana se ha referido a tal separación en el contexto de los procedimientos de expulsión, pero nada impide considerar esa misma situación

139 Ley No 25.871 (2004), art. 29. La potestad excepcional otorgada a la autoridad administrativa resulta doblemente desacertada, por exceso y por defecto. Por exceso, porque no se excluye de esta potestad ninguno de los supuestos de impedimento (la autoridad administrativa podría dispensar del impedimento, por ejemplo, a un genocida condenado por el Tribunal Penal Internacional que tiene algún vínculo familiar con un residente en Argentina). Por defecto, porque en aquellos casos en que la ponderación exige favorecer al extranjero, la situación de éste queda a merced de la discrecionalidad administrativa. Ver ejemplos en este sentido en Ceriani Cernadas (2005), p. 347.

140 Condición jurídica y derechos humanos del niño, Corte IDH, OC-17/02, serie A No 17, 2002. Derechos y garantías de niñas y niños en el contexto de la migración y/o en necesidad de protección internacional, Corte IDH, OC-21/14, serie A No 21, 2014. Caso de personas dominicanas y haitianas expulsadas, Corte IDH, serie C No 282, 2014. 
en relación con la admisión al territorio. Así como la expulsión del territorio puede significar la separación del menor y sus progenitores, también puede darse esta separación si los progenitores o alguno de ellos son admitidos al territorio sin que se asegure un procedimiento para reagrupar a los hijos menores. En efecto, el Estado no sólo tiene el deber de no romper la unidad familiar mediante la expulsión, sino también el deber positivo de adoptar medidas que permitan la reagrupación familiar. Sin embargo, esto no quiere decir que el derecho del menor a no ser separado de sus progenitores se imponga siempre a la facultad soberana de los Estados de decidir sus políticas migratorias. Es necesario realizar un ejercicio de ponderación entre la unidad familiar, por un lado, y la decisión migratoria que implica su ruptura, por otro; y por supuesto es necesario que tal decisión sea adoptada de conformidad con la ley y persiga un fin legítimo (si estos dos últimos requisitos no se dan, la decisión será de por sí ilegítima, sin necesidad de realizar el ejercicio de ponderación) ${ }^{141}$.

\section{PRIVACIÓn DE LiBERTAd EN VISTAS A LA EXPUlsión}

Un último punto a tratar es el relativo a la afectación de la libertad de los extranjeros en vistas al ejercicio de las potestades estatales de admisión o expulsión. En efecto, es posible que la libertad de un extranjero se vea afectada por el ejercicio de las funciones de control de ingreso al territorio o en orden a garantizar una futura expulsión.

De acuerdo con la jurisprudencia de la Corte Suprema, la autoridad administrativa puede restringir la libertad de movimientos de un extranjero que intenta entrar irregularmente al territorio. Hasta que su situación sea resuelta por esa autoridad, o hasta que el extranjero decida voluntariamente abandonar el país, puede ser retenido en un centro especializado ${ }^{142}$. La Ley de Migraciones dispone que si hay dudas sobre los motivos de la entrada, el extranjero debe permanecer en las instalaciones del puesto de control migratorio durante el tiempo de verificación de estos motivos (aunque la ley se refiere sólo a las dudas sobre los

141 Derechos y garantias de niñas y niños en el contexto de la migración y/o en necesidad de protección internacional, Corte IDH, OC-21/14, serie A No 21, 2014. Caso de personas dominicanas y haitianas expulsadas, Corte IDH, serie C No 282, 2014.

142 Grunblatt, CSJN, Fallos 210:558, 1948. En el caso, se trataba de la detención del extranjero en el Hotel de Inmigrantes. La Corte rechazó el habeas corpus. Aunque a nuestro juicio se trataba de una verdadera expulsión, la Corte calificó el caso como de rechazo en frontera (es decir, reconducción al extranjero de alguien que todavía no ha ingresado al territorio), porque el extranjero había entrado irregularmente al país. 
motivos de entrada, parece que la misma retención en las instalaciones de control migratorio podría aplicarse en otros supuestos de duda sobre si están cumplidos los requisitos de ingreso) ${ }^{143}$. Si la entrada es finalmente denegada, la reconducción del extranjero debe hacerse en el plazo más breve posible ${ }^{144}$.

El supuesto sin dudas más controvertido es el de la privación de libertad en casos de expulsión. Bajo la vigencia de leyes anteriores la Corte Suprema convalidó tanto la potestad administrativa de privar de libertad a una persona en orden a garantizar su futura expulsión como el ejercicio más o menos discrecional de esa facultad. Bajo la vigencia de la Ley de Residencia, la Corte Suprema resolvió que era legítima la potestad reconocida a la autoridad administrativa de restringir la libertad de movimiento del extranjero en vistas a su deportación y que, como cuestión de principio, la privación de libertad podía durar el tiempo que fuera necesario para hacer efectiva la deportación ${ }^{145}$.

Sin embargo, en dos casos insinuó que la extensión de esta privación de libertad no podía ir más allá de lo razonable ${ }^{146}$. Más adelante, y aplicando esa doctrina, la Corte ordenó que una persona que había permanecido más de diez meses privada de su libertad en vistas a la expulsión fuera inmediatamente expulsada o puesta en libertad ${ }^{147}$. Lo decisivo para resolver este último caso fue que la ausencia de relaciones entre la Argentina y el país de origen del extranjero hacía imposible conseguir el pasaporte y no se preveía que esa situación pudiera cambiar. Inversamente, no hay violación de derechos constitucionales si la detención se prolonga

143 Ley No 25.871 (2004), art. 35.

144 Decreto No 616/2010, art. 35.

145 Groisman, CSJN, Fallos 173:135, 1935. Berezeski, CSJN, Fallos 178:361, 1937. Cantor, CSJN, Fallos 180:196, 1937. S. de Mysliwiec, CSJN, Fallos 218:769, 1950.

146 Dictamen del Procurador Fiscal al que remite la sentencia de la Corte en Groisman, CSJN, Fallos 173:135, 1935. Se trataba de un habeas corpus en favor de un extranjero que había permanecido varios meses privado de su libertad a la espera de la ejecución de la expulsión en el marco de la Ley de Residencia. Además de las complicaciones relativas a la organización del viaje hasta Rumanía, de donde era originario, la demora era debida a los reparos puestos por el cónsul del país de su nacionalidad a otorgar el pasaporte. La Corte aceptó implícitamente el principio postulado por el Procurador Fiscal pero no consideró que la duración de la privación de libertad hubiera sido irrazonable en el caso concreto. Caso similar tratado en Berezeski, CSJN, Fallos 178:361, 1937.

147 Cantor, CSJN, Fallos 180:196, 1937. Habeas corpus en favor de una persona privada de su libertad en vistas a la ejecución de una orden de expulsión. La expulsión no se podía ejecutar porque, no teniendo la Argentina relaciones diplomáticas ni consulares con la Rusia soviética, no era posible conseguir el pasaporte para el extranjero. 
por causa imputable al extranjero, que no presenta los documentos necesarios para hacer efectiva su deportación ${ }^{148}$.

La anterior Ley General de Migraciones y de Fomento de la Inmigración también admitía la detención del extranjero por orden administrativa, aunque siempre por el tiempo "estrictamente indispensable para hacer efectiva la expulsión" 149. Cuando no pudiera realizarse esa expulsión en un plazo prudencial o mediaran causas justificadas, la autoridad podía ordenar la puesta en libertad del extranjero bajo caución ${ }^{150}$. Bajo ese régimen los tribunales ejercieron el control de la duración de la privación de libertad del extranjero en vistas a su expulsión ${ }^{151}$. La Corte Suprema, sin negar el principio de la posibilidad de revisión de judicial de la razonabilidad de la duración de la privación de libertad, hizo una aplicación poco estricta de sus facultades de control. En el caso Cai Wenhuang, Yang Guoqiang y Yang Aiqiong, consideró que una detención de veintidós días no excedía el plazo de lo razonable, teniendo en cuenta que la propia ley establecía que los recursos presentados contra la resolución de expulsión no suspendían la detención precautoria y que el plazo para resolver esos recursos no se había agotado todavía. Al resolver, la Corte dejó en claro que la facultad dada por la ley al Poder Ejecutivo para ordenar la privación de libertad de un extranjero en vistas a su expulsión no comportaba el ejercicio de la jurisdicción criminal, sino la aplicación de medidas cautelares "para el efectivo control de ingreso y permanencia de extranjeros en el país" 152 .

A diferencia de lo que sucedía en las dos leyes referenciadas, la actual Ley de Migraciones deja la decisión sobre la eventual privación de libertad en manos de

148 S. de Mysliwiec, CSJN, Fallos 218:769, 1950. El habeas corpus había sido presentado en beneficio de un grupo de extranjeros detenidos en vistas a su deportación, que no exhibían los documentos de identidad necesarios para hacer efectiva la expulsión.

149 Ley No 22.439 (1981), art. 40.

150 Ley No 22.439 (1981), art. 41. El otorgamiento de la libertad bajo caución era potestativo (Ortega, Rosario s/ habeas corpus, Cámara Nacional de Apelaciones en lo Criminal y Correccional, sala 6, 2003).

151 La privación de libertad de un extranjero en vistas a su expulsión no puede prolongarse por un lapso que excede al que corresponde a sospechosos por la comisión de delitos (Pérez, Maricel s/ Habeas corpus, Cámara Nacional de Apelaciones en lo Criminal y Correccional, sala 5, 2002). Tampoco es razonable una privación de libertad de 15 días con el solo fundamento de una futura expulsión si no existe una fecha, siquiera aproximada, para que ella se haga efectiva (Lin Wun Qiang s/ habeas corpus, Cámara Nacional de Apelaciones en lo Criminal y Correccional, sala 7, 2003).

152 Dictamen del Procurador Fiscal al que remite la mayoría de la Corte en Cai Wenhuang, Yang Guoqiangy Yang Aiqiong, CSJN, Fallos 327:931, 2004. El caso era relativo a un grupo de ciudadanos chinos detenidos con vistas a su expulsión. 
los jueces. Así, cuando la decisión de expulsión sea firme y definitiva, el Ministerio del Interior o la Dirección Nacional de Migraciones deben solicitar a la autoridad judicial la detención; excepcionalmente, la detención puede ser solicitada incluso si la decisión de expulsión no es todavía firme y definitiva ${ }^{153}$. El tiempo de detención no puede ir más allá del estrictamente necesario para hacer efectiva la expulsión ${ }^{154}$. Una vez el extranjero detenido, la autoridad administrativa puede ordenar su libertad bajo fianza si la expulsión no puede hacerse efectiva en un plazo razonable o si las circunstancias justifican esta libertad ${ }^{155}$.

Según la jurisprudencia interamericana, las garantías de la legalidad ${ }^{156}$ y la no arbitrariedad ${ }^{157}$ se extienden a cualquier privación de libertad. La privación de libertad de las personas en el contexto de un procedimiento migratorio es legítima siempre que sea necesaria y proporcionada en el caso concreto, durante el menor tiempo posible y en atención a los fines legítimos relativos al control migratorio ${ }^{158}$.

Por último, una consideración particular en relación con la privación de libertad merece el caso de los menores. Según la Corte Interamericana, los Estados no pueden recurrir a la privación de libertad de menores para cautelar los fines de un proceso migratorio, sino que deben disponer de alternativas menos lesivas. En consecuencia, y en la medida en que sea necesario para garantizar el principio de unidad familiar, debe disponerse también la puesta de libertad de los progenitores ${ }^{159}$.

153 Ley No 25.871 (2004), art. 70. Para poder aplicar la privación de libertad antes de que el acto de expulsión esté firme es necesario que se prueben circunstancias verdaderamente excepcionales. Azeng Xiankai s/habeas corpus, Cámara Federal de Apelaciones de Paraná, 2004. Ali, Yun, Lingyan Zheng y Yu Junyun s/ habeas corpus, Cámara Federal de Paraná, 2004.

154 Ley No 25.871 (2004), art. 70.

155 Ley No 25.871 (2004), art. 71.

156 Convención Americana sobre Derechos Humanos, art. 7.2; Declaración Americana de los Derechos y Deberes del Hombre, art. XXV.

157 Convención Americana sobre Derechos Humanos, art. 7.3.

158 Vélez Loor, Corte IDH, serie C No 218, 2010. Nadège Dorzema, Corte IDH, serie C No 251, 2012. Personas dominicanas y haitianas expulsadas, Corte IDH, serie C No 282, 2014. Informe sobre la Situación de derechos humanos de las personas que buscan asilo dentro del sistema canadiense de determinación de la condición de refugiado, Comisión IDH, OEA/Ser.L/V/II.106 Doc. 40 Rev., 2000. Rafael Ferrer-Mazorra y otros, Comisión IDH, informe 51/01, caso 9903, 2001. Sobre la privación de libertad de migrantes, desde la perspectiva del derecho interamericano de los derechos humanos, ver RELATORía sobre LOS DERECHOS DE los Migrantes (2011) y Relatoría sobre los Derechos de los Migrantes (2011), capítulo 5.

159 Derechos y garantías de niñas y niños en el contexto de la migración y/o en necesidad de protección internacional, Corte IDH, OC-21/14, serie A No 21, 2014. Personas dominicanas y haitianas expulsadas, Corte IDH, serie C No 282, 2014. Ver Arlettaz (2016b). 


\section{CONCLUSIONES}

La potestad estatal de admitir o denegar la entrada a extranjeros, así como la potestad de expulsarlos, están bien asentadas en derecho internacional. El derecho internacional vigente no es (o no es todavía) un derecho cosmopolita que autorice a cualquier ser humano a circular libremente y establecerse en el territorio de cualquier Estado. Es (todavía) un derecho internacional basado en la soberana potestad estatal de regular los movimientos de personas. Sin embargo, existe una tendencia creciente a morigerar esa potestad estatal que, por otra parte, nunca se ha reconocido como absolutamente discrecional.

La Constitución argentina, aunque muy generosa en cuanto a los derechos de los migrantes, se mantuvo dentro de los cánones del derecho internacional y dio a la autoridad estatal competencia para regular el ingreso y salida de extranjeros. Con idas y vueltas, dependientes de las variables políticas de cada momento, la exégesis constitucional propiciada por la Corte Suprema de Justicia reconoció limitaciones a las potestades estatales por la vía de garantías individuales en favor de los extranjeros.

La labor humanizadora desempeñada, con mayor o menor éxito, por los principios constitucionales está hoy reforzada por las garantías que fluyen de los instrumentos internacionales de protección de los derechos humanos. En especial, la Convención Americana de Derechos Humanos y la interpretación que de ella han hecho la Corte y la Comisión Interamericanas inciden centralmente en la limitación de las potestades estatales relativas a la admisión y expulsión de extranjeros. Sin embargo, aunque limitan esas potestades, no las hacen desaparecer totalmente.

Uno de los ámbitos en los que la situación de los extranjeros se ha visto protegida por la recepción del derecho internacional de los derechos humanos es el de las expulsiones. Los instrumentos internacionales de carácter general receptan el principio de legalidad en relación con la expulsión, así como otras garantías procesales. La Convención sobre los Trabajadores Migratorios es todavía más específica a este respecto.

Por otra parte, aunque ni las fuentes internas ni las internacionales recogen un derecho absoluto a ingresar o permanecer en un Estado que no sea el propio, en algunos casos ese derecho puede derivarse de otros principios constitucional o internacionalmente admitidos. Tal es el caso de la protección de la familia, que exige que, al menos en lo que se refiere a los familiares más próximos, tal derecho sea reconocido. 


\section{REFERENCIAS}

\section{BibLIOGRAFía CITADA}

ArlettAZ, Fernando (2014): "Extranjeros, migrantes y trabajadores migrantes en la jurisprudencia interamericana", en Revista de derecho migratorio y extranjería (No 36), pp. 247-260.

Arlettaz, Fernando (2016a): "La expulsión de extranjeros en el Pacto Internacional de Derechos Civiles y Políticos", en Boletín Mexicano de Derecho Comparado (No 145), pp. 13-45.

ArletTAZ, Fernando (2016b): "Perspectiva interamericana sobre la afectación de libertad de menores en procedimientos migratorios", en Anuario Colombiano de Derecho Internacional (No 9), pp. 197-231.

Ceriani Cernadas, Pablo (2005): "A dos años de la nueva Ley de Migraciones: avances, cuestiones pendientes y casos preocupantes", en Centro de Estudios Legales y Sociales, Informe 2005 - Derechos Humanos en Argentina (Buenos Aires, CELS), pp. 337-360.

Chausovsky, Gabriel (2004): "Apuntes jurídicos para la nueva Ley de Migraciones”, Rubén Giustiniani, Migración. Un derecho humano (Buenos Aires, Prometeo), pp. 159-171.

Federación Internacional de Derechos Humanos-Centro de Estudios Legales y Sociales (2011): Argentina. Avances y asignaturas pendientes en la consolidación de una política migratoria basada en los derechos humanos (Buenos Aires, FIDH).

Gordillo, Agustín (2004): "El inmigrante irregular en la Ley 25871. Otra modificación transversal al derecho argentino", en La Ley (No 2004-B), pp. 1123 y ss.

GuASTI, Luis Alejandro (2014): "Poder de policía migratorio: problemas y características del régimen de expulsión de extranjeros", DJ, 16/04/2014, p. 95.

GuASTI, Luis Alejandro (2017): "El control de convencionalidad de la política migratoria a la luz de la última modificación de la Ley No 25.871", El Derecho, septiembre-2017.

Hines, Barbara (2010): "The Right to Migrate as a Human Right: The Current Argentine Immigration Law”, en Cornell International Law Journal (No 433), pp. 471-511.

Instituto Nacional de Estadística y Censos (2010), Censo nacional de población, hogares y viviendas, fecha de consulta: 2 de febrero de 2017. Dispo- 
nible en: http://www.indec.gov.ar/censos_total_pais.asp?id_tema_1=2\&id_ tema_2=41\&id_tema_3=135\&t=3\&s=7\&c=2010.

KAMTO, Maurice (2005), Informe preliminar sobre la expulsión de los extranjeros, UN Doc. A/CN.4/554.

KamTo, Maurice (2006), Segundo informe sobre la expulsión de los extranjeros, UN Doc. A/CN.4/573.

KAMTO, Maurice (2007), Tercer informe sobre la expulsión de los extranjeros, UN Doc. A/CN.4/581.

KAмTO, Maurice (2008), Cuarto informe sobre la expulsión de los extranjeros, UN Doc. A/CN.4/594.

KAMTO, Maurice (2009), Quinto informe sobre la expulsión de los extranjeros, UN Doc. A/CN.4/611.

Kamto, Maurice (2010), Sexto informe sobre la expulsión de los extranjeros, UN Doc. A/CN.4/625.

KAMTO, Maurice (2011), Séptimo informe sobre la expulsión de los extranjeros, UN Doc. A/CN.4/642.

KamTO, Maurice (2012), Octavo informe sobre la expulsión de los extranjeros, UN Doc. A/CN.4/651.

Novick, Susana (2004), "Una nueva ley para un nuevo modelo de desarrollo en un contexto de crisis y consenso", en Giustiniani, Rubén (ed.), La migración: un derecho humano (Buenos Aires, Prometeo).

Novick, Susana (2008), "Migración y políticas en la Argentina: tres leyes para un país extenso (1876-2004)", en NovicK, Susana (coord.), Las migraciones en América Latina. Políticas, culturas y estrategias (Buenos Aires, CLACSO).

Relatoría sobre los Derechos de los Migrantes (2011), Informe sobre inmigración en Estados Unidos: detenciones y debido proceso, OEA/Ser.L/V/II Doc. $78 / 10$.

Relatoría sobre los Derechos de los Migrantes (2015), Derechos humanos de migrantes, refugiados, apátridas, víctimas de trata de personas y desplazados internos: normas y estándares del Sistema Interamericano de Derechos $\mathrm{Hu}$ manos, OEA/Ser.L./V/II Doc. 46/15.

Rodríguez Miglio, Ezequiel y Toledo, Leonel (2009): "Jurisprudencia argentina en materia de derechos de migrantes", en Ceriani Cernadas, Pablo y Fava, Ricardo (eds.), Políticas migratorias y derechos humanos (Lanús, Ediciones UNLa). 


\section{NORMAS JURÍDICAS CITADAS}

Constitución de la Nación Argentina (1853, y reformas de 1860, 1957 y 1994). Constitución de la Nación Argentina (1949).

Ley No 817, de Inmigración y Colonización. Sancionada el 6/10/1876, Registro Nacional 1874/77, p. 491.

Ley No 4.144, de Residencia. Sancionada el 22/11/1902, Boletín Oficial de 25/11/1902.

Ley No 7.029, de Defensa Social. Sancionada el 28/06/1910, Boletín Oficial de $3 / 11 / 1921$.

Ley No 22.439, General de Migraciones y de Fomento de la Inmigración. Sancionada el 16/03/1981, Boletín Oficial de 27/03/1981.

Ley No 25.871, de Migraciones. Sancionada el 17/12/2003, Boletín Oficial de $21 / 01 / 2004$.

Decreto No 1.434, Reglamento de Migraciones. Adoptado el 31/08/1987, Boletín Oficial de 17/09/1987.

Decreto No 1.023, Reglamento de Migraciones. Adoptado el 29/06/1994, Boletín Oficial de 5/07/1994.

Decreto No 616, Reglamentación de la Ley de Migraciones. Adoptado el 3/05/2010, Boletín Oficial de 6/05/2010.

Pacto Internacional de Derechos Civiles y Políticos, adoptado en Nueva York el 19/12/1966. Ratificado por Argentina el 8/08/1986 (Ley No 23.313, sancionada el 17/04/1986, Boletín Oficial 13/05/1986).

Convención de Viena sobre Relaciones Consulares, adoptada en Viena el 24/04/1963. Ratificada por Argentina el 7/03/1967 (Ley No 17.081, sancionada el 23/12/1966, Boletín Oficial 12/01/1967).

Convención Americana sobre Derechos Humanos, adoptada en San José, Costa Rica, el 22/11/1969. Ratificada por Argentina el 14/08/1984 (Ley No 23.054, sancionada el 1/03/1984, Boletín Oficial de 27/03/1984).

Convención sobre el Estatuto de los Refugiados, adoptada en Ginebra, Suiza, el 28/07/1951. Adherida por Argentina el 15/11/1961 (Ley No 15.869, Boletín Oficial de 11/10/1961).

Convención Internacional sobre la Protección de los Derechos de Todos los Trabajadores Migratorios y sus Familiares, adoptada por Resolución No 45/158 de la Asamblea General de las Naciones Unidas, el 18/12/1990. Ratificada por Argentina el 23/02/2007 (Ley No 26.202, Boletín Oficial de 17/01/2007). 
Declaración Americana de Derechos y Deberes del Hombre, aprobada en la IX Conferencia Internacional Americana, Bogotá, Colombia, 1948.

Declaración Universal de Derechos Humanos, adoptada por Resolución No 217 A (III) de la Asamblea General de las Naciones Unidas el 10/12/1948.

Resolución No 40/144 de la Asamblea General de las Naciones Unidas, sobre los derechos humanos de los individuos que no son nacionales del país en que viven, 13/12/1985.

\section{JURISPRUDENCIA CITADA}

Sentencias de la Corte Suprema de Justicia de la Nación (Argentina). Se las cita de acuerdo con su ubicación en la colección oficial de sentencias de la Corte Suprema (Fallos). Su texto puede consultarse en www.csjn.gov.ar/sentenciasacordadas-y-resoluciones.

Pedro Miguel, Esteban Juan y otros, Corte Suprema de Justicia de la Nación, Fallos 117:165, 1913.

Magaz de González, Corte Suprema de Justicia de la Nación, Fallos 148:410, 1926. Maciá y Gassol, Corte Suprema de Justicia de la Nación, Fallos 151:211, 1928.

Bertone, Corte Suprema de Justicia de la Nación, Fallos 164:290, 1932.

Transporte Chaco, Corte Suprema de Justicia de la Nación, Fallos 164:344, 1932.

Psaradelis, Corte Suprema de Justicia de la Nación, Fallos 171:310, 1934.

Groisman, Corte Suprema de Justicia de la Nación, Fallos 173:135, 1935.

Hernández, Corte Suprema de Justicia de la Nación, Fallos 173:179, 1935.

Berezeski, Corte Suprema de Justicia de la Nación, Fallos 178:361, 1937.

Cantor, Corte Suprema de Justicia de la Nación, Fallos 180:196, 1937.

Di Cesare, Corte Suprema de Justicia de la Nación, Fallos 184:101, 1939.

Kaiser, Corte Suprema de Justicia de la Nación, Fallos 183:373, 1939.

Bunge, Corte Suprema de Justicia de la Nación, Fallos 186:421, 1940.

Gagliotti, Corte Suprema de Justicia de la Nación, Fallos 188:326, 1940.

Rodríguez, Corte Suprema de Justicia de la Nación, Fallos 197:332, 1943.

Cuesta Urrutia, Corte Suprema de Justicia de la Nación, Fallos 200:99, 1944.

Doregger, Corte Suprema de Justicia de la Nación, Fallos 203:256, 1945.

Rial y Freire, Corte Suprema de Justicia de la Nación, Fallos 205:628, 1946.

Watjen, Corte Suprema de Justicia de la Nación, Fallos 204:571, 1946.

Barwins, Corte Suprema de Justicia de la Nación, Fallos 212:101, 1948. 
Grunblatt, Corte Suprema de Justicia de la Nación, Fallos 210:558, 1948.

Ordinanz, Corte Suprema de Justicia de la Nación, Fallos 215:161, 1949.

S. de Mysliwiec, Corte Suprema de Justicia de la Nación, Fallos 218:769, 1950.

Zovrko, Corte Suprema de Justicia de la Nación, Fallos 218:490, 1950.

Mizzau, Corte Suprema de Justicia de la Nación, Fallos 230:252, 1954.

Lino Sosa, Corte Suprema de Justicia de la Nación, Fallos 234:203, 1956.

Argüello Argüello, Corte Suprema de Justicia de la Nación, Fallos 268:393, 1967.

Britez, Corte Suprema de Justicia de la Nación, Fallos 268:406, 1967.

Ventura, Corte Suprema de Justicia de la Nación, Fallos 294:152, 1976.

Carrizo Coito, Corte Suprema de Justicia de la Nación, Fallos, 302:604, 1980.

Cardozo Galeano, Corte Suprema de Justicia de la Nación, Fallos 313:101, 1990.

De la Torre, Corte Suprema de Justicia de la Nación, Fallos 321:3646, 1998.

Lufthansa, Corte Suprema de Justicia de la Nación, Fallos 328:2909, 1999.

Cai Wenhuang, Yang Guoqiang y Yang Aiqiong, Corte Suprema de Justicia de la Nación, Fallos 327:931, 2004.

Zhang, Corte Suprema de Justicia de la Nación, Fallos 330:4554, 2007.

Ojeda Hernández, Corte Suprema de Justicia de la Nación, O. 113. XLVIII. RHE, 2014.

Dictámenes del Procurador ante la Corte Suprema de Justicia de la Nación (Argentina). Los dictámenes son publicados juntamente con las sentencias de la Corte Suprema (ver más arriba).

Hernández, Dictamen del Procurador Fiscal, Fallos 173:179, 1935.

Argüello Argüello, Dictamen del Procurador Fiscal, Fallos 268:393, 1967.

Cai Wenhuang, Yang Guoqiang y Yang Aiqiong, Dictamen del Procurador Fiscal, Fallos 327:931, 2004.

Sentencias de otros tribunales argentinos. Pueden consultarse en www.saij.gob. ar, con excepción de la sentencia de Cámara en el asunto Transporte Chaco, que fue publicada juntamente con la sentencia de la Corte Suprema en ese mismo asunto (ver más arriba).

Transporte Chaco, Cámara Federal de Apelaciones de la Capital, 1932.

Pérez, Maricel s/ Habeas corpus, Cámara Nacional de Apelaciones en lo Criminal y Correccional, sala 5, 2002.

Lin Wun Qiang s/ habeas corpus, Cámara Nacional de Apelaciones en lo Criminal y Correccional, sala 7, 2003. 
Ortega, Rosario s/ habeas corpus, Cámara Nacional de Apelaciones en lo Criminal y Correccional, sala 6, 2003.

Ali, Yun, Lingyan Zheng y Yu Junyun s/ habeas corpus, Cámara Federal de Apelaciones de Paraná, 2004.

Azeng Xiankai s/habeas corpus, Cámara Federal de Apelaciones de Paraná, 2004.

Dictamen del Procurador Fiscal ante otros tribunales argentinos. El dictamen que se cita fue publicado juntamente con la sentencia de la Corte Suprema en ese mismo asunto (ver más arriba).

Transporte Chaco, Dictamen del Procurador Fiscal en Juzgado de Primera Instancia (no se indica cuál), 1932.

Sentencias y Opiniones Consultivas de la Corte Interamericana de Derechos Humanos. Pueden consultarse en www.corteidh.or.cr/index.php/jurisprudencia.

El derecho a la asistencia consular en el marco de las garantías del debido proceso legal, Corte Interamericana de Derechos Humanos, serie A No 16, 1999.

Condición jurídica y derechos humanos del niño, Corte Interamericana de Derechos Humanos, OC-17/02, serie A No 17, 2002.

Condición jurídica y derechos de los migrantes indocumentados, Corte Interamericana de Derechos Humanos, OC-18/03, serie A No 18, 2003.

Vélez Loor, Corte Interamericana de Derechos Humanos, serie C No 218, 2010.

Nadège Dorzema, Corte Interamericana de Derechos Humanos, serie C No 251, 2012.

Derechos y garantías de niñas y niños en el contexto de la migración y/o en necesidad de protección internacional, Corte Interamericana de Derechos Humanos, OC-21/14, serie A No 21, 2014.

Personas dominicanas y haitianas expulsadas, Corte Interamericana de Derechos Humanos, serie C No 282, 2014.

Informes de la Comisión Interamericana de Derechos Humanos. Pueden consultarse en www.oas.org/es/cidh/decisiones/casos.asp, con excepción del informe sobre el asilo en Canadá, que aparece en www.cidh.org/countryrep/ Canada2000sp/canada.htm.

Stetter, Comisión Interamericana de Derechos Humanos, informe 30/81, caso 7378, 1981.

Joseph, Comisión Interamericana de Derechos Humanos, informe 27/93, caso $11092,1993$.

Riebe Star, Barón Guttlein e Izal Elorz, Comisión Interamericana de Derechos Humanos, informe 49/99, caso 11610, 1999. 
Informe sobre la Situación de derechos humanos de las personas que buscan asilo dentro del sistema canadiense de determinación de la condición de refugiado, Comisión Interamericana de Derechos Humanos, OEA/Ser.L/V/II.106 Doc. 40 rev., 2000.

Rafael Ferrer-Mazorra y otros, Comisión Interamericana de Derechos Humanos, informe 51/01, caso 9903, 2001.

De la Torre, Comisión Interamericana de Derechos Humanos, informe 85/11, caso 12306, 2011.

Informe del Comité de Derechos Humanos de Naciones Unidas. Puede consultarse en www2.ohchr.org/spanish/bodies/hrc/.

Observación General número 15. La situación de los extranjeros con arreglo al Pacto, Comité de Derechos Humanos, HRI/GEN/1/Rev.7, at 159, 1986. 